\title{
Privileging Electric Vehicles as an Element of Promoting Sustainable Urban Mobility-Effects on the Local Transport System in a Large Metropolis in Poland
}

\author{
Marta Borowska-Stefańska ${ }^{1, *} \mathbb{D}$, Michał Kowalski ${ }^{1} \mathbb{D}$, Paulina Kurzyk ${ }^{1}$, Miroslava Mikušová ${ }^{2} \mathbb{D}$ \\ and Szymon Wiśniewski ${ }^{1}$ D \\ 1 Faculty of Geographical Sciences, University of Lodz, 90-142 Łódź, Poland; \\ michal.kowalski@geo.uni.lodz.pl (M.K.); paulina.kurzyk@geo.uni.lodz.pl (P.K.); \\ szymon.wisniewski@geo.uni.lodz.pl (S.W.) \\ 2 Faculty of Operation and Economics of Transport and Communications, University of Zilina, \\ 01026 Zilina, Slovakia; mikusova@fpedas.uniza.sk \\ * Correspondence: marta.borowska@geo.uni.lodz.pl
}

check for

updates

Citation: Borowska-Stefańska, M.; Kowalski, M.; Kurzyk, P.; Mikušová, M.; Wiśniewski, S. Privileging Electric Vehicles as an Element of Promoting Sustainable Urban Mobility-Effects on the Local Transport System in a Large Metropolis in Poland. Energies 2021, 14, 3838. https://doi.org/ $10.3390 /$ en14133838

Academic Editor: João Pedro Trovao

Received: 31 May 2021

Accepted: 24 June 2021

Published: 25 June 2021

Publisher's Note: MDPI stays neutral with regard to jurisdictional claims in published maps and institutional affiliations.

Copyright: (c) 2021 by the authors. Licensee MDPI, Basel, Switzerland. This article is an open access article distributed under the terms and conditions of the Creative Commons Attribution (CC BY) license (https:// creativecommons.org/licenses/by/ $4.0 /)$.

\begin{abstract}
The main purpose of this article was to determine the impact on the equilibrium of the local transport system from privileging EVs by permitting them to use bus lanes. The study used two sets of data: information on infrastructure and traffic management; and information on the recorded road network loads and traffic volumes generated by a given shopping centre-the E. Leclerc shopping centre (an important traffic generator within the city of Łódź, Poland). These sets were then used to develop a microsimulation traffic model for the shopping centre and the associated effects on the localised transport system. The model was constructed by means of the PTV Vissim software tool. An initial simulation was conducted that formed a basis for subsequent scenarios (in total, 17 simulations were performed). On the basis of the conducted analyses, it was established that-for the researched part of the transport system-privileging the still rather uncommon battery electric vehicles (BEVs) engendered a marginal deterioration of traffic conditions. At the same time, allowing BEVs to use bus lanes within the chosen research area had no negative impact on bus journey times.
\end{abstract}

Keywords: electric vehicles; EVs; battery electric vehicles; BEVs; sustainable transport; mobility; traffic microsimulation; intelligent transport system; ITS; transport inequity

\section{Introduction}

In Poland, where a private car is still perceived as something of a status symbol by a substantial number of citizens [1], and especially in large Polish cities, one can easily observe how complex it is to implement electromobility as yet another transport solutionespecially when some people would even be willing to give up the idea of car ownership if the alternatives of city transport met their specific transport needs [2].

Before the idea of electromobility was recognised at governmental level and then delegated to lower grades of public administration, major Polish cities were a testing ground for the first such initiatives, which were often of an episodic or experimental nature. These included decisions to purchase electric buses and to launch EV car-sharing programmes in order to improve air quality, reduce noise levels, and raise standards of passenger transport. Furthermore, these decisions were also partially triggered by regional green marketing.

Although a national policy on the main electromobility [3] objectives has been established, as well as the tools for its implementation and the indicators by which to measure the efficiency of the whole process, the burden of implementation still lies with local governments. This particularly concerns those authorities of regions where transport systems play a crucial role, i.e., large cities. This has resulted in local governments having to develop 
and effectively implement their own mobility strategies, which include an objective to increase the importance and presence of EVs. Implementation of the objectives of mass transit-which in large cities is customarily controlled by local authorities-is primarily a financial challenge, since it usually means replacing the existing fossil-fuel-powered bus fleet with vehicles that have alternative and more eco-friendly powertrains. The ongoing shift to electromobility in public transport (here: buses) also involves the need to adapt to the challenges that the applied technology imposes (e.g., extra time allocated to charging vehicles), yet all of these procedures are mainly coordinated and controlled by local governments [4]. Another issue is the percentage of vehicle-kilometres and passenger-kilometres covered by eco-friendly vehicles against the total value of these parameters for a given public transport system.

The implementation of the objective of increasing the share of privately owned EVs requires radical thinking. Even though large cities have successfully introduced electric rental alternatives to public transport (e.g., scooters, bikes, mopeds, etc.), encouraging privately owned electric car transport still remains quite a challenge. Admittedly, there are some shared vehicle fleets, but EVs usually constitute just a tiny fraction of these.

Currently, city authorities are facing a most difficult task related to the development of public transport-changing transport behaviour. In the case of private vehicle use, factors that make it even more formidable are the financial barrier (the high prices of EVs), the psychological barrier (distrust towards the technology behind fully electric powertrains due to concerns about limited charging possibilities in emergency situations and the relatively low driving range), and the infrastructural barrier (e.g., an insufficient network of fast charging stations).

However, it should be stressed that the technology related to the process of charging vehicles and the durability of their batteries is constantly and dynamically developing [5]. The solutions being developed are designed to reduce the time required to charge the battery while minimising the impact on battery longevity [6,7]. On the other hand, efforts to develop the batteries themselves concentrate on increasing their capacity, prolonging the period of time for which they can provide energy of appropriate parameters, and extending their useful life [8-11]. These actions are intended to fulfil both the objective of increasing the effectiveness/convenience of their use for final consumers (in this case, drivers of passenger cars) and the objective of limiting their negative impact on the environmentfor instance, during their production, or at the end of their useful life [12,13]. With the emergence of greater awareness of sustainable and clean energy, batteries with lithium-ion technology, among others, have found widespread use in energy storage systems, including in electric vehicles. However, in order for this technology to meet the adopted performance criteria for batteries, it is necessary to manage the production chain precisely (which, as a result, is also less harmful to the environment). Electric and hybrid vehicles are associated with green technologies and the reduction of greenhouse gas emissions. They nevertheless contribute to increased environmental degradation through excessive demand for energy sources (especially in countries with limited access to renewable energy sources). The chemical and electronic components of car batteries, and their handling when they have lost their service value, involve continuous investment in the latest recycling technology, since it is necessary to limit the spread of electronic waste into the environment. Currently, many types of battery technology can be used in electric vehicles-including, for instance, lead-acid ( $\mathrm{Pb}$-acid), nickel-cadmium (Ni-Cd), nickel-metal hydride (Ni-MH), lithium-ion (Li-ion), lithium-ion polymer, and sodium-nickel chloride (Na-NiCl). Although individual solutions have different performance characteristics, none of them remain indifferent to nature. From this perspective, the development of biological systems for energy production in the context of bio-batteries seems to be an interesting alternative [5]. It can thus be assumed that there will be a steady decrease in the role of technological and infrastructural barriers to the widespread use of electric and hybrid vehicles as a means of private transport.

In order to remove these barriers, local authorities are striving to overcome these "blank spots" on the map of charging stations, which pose a problem due to land ownership 
issues, the nature of land use in a given location, traffic management, and connection to the city's often overloaded power grid. Furthermore, local governments may also impact residents' transport behaviour using so-called "soft" incentives or restrictions-the purpose of which is to privilege EVs when it comes to driving and parking within the urban area with regard to time, costs, etc. Such incentives may include free parking and unrestricted access to bus lanes. These are often implemented simultaneously with deterrents aimed at those vehicles considered exceptionally harmful to the environment. Alas, these actions are not undertaken at a sufficient scale, since there are legal, administrative, and political barriers, along with no public pressure due to lack of awareness. Moreover, when it comes to the stimulative role of local governments, it must be stated that they should aim to stay ahead of the curve in introducing new trends, instead of waiting passively for the price erosion of EV technology that may, with time, stem from further development and widespread popularisation of electromobility. The most vital initiatives are those that could either optimise or limit the deployment of infrastructure to critical spots, e.g., areas where a shortage of charging stations drastically restricts the usability of EVs. Importantly, local authorities must not fail to look for possible synergy between the development of charging infrastructure for cars and its own public transport [14].

The main purpose of this article was to determine the impact on the equilibrium of the local transport system from privileging EVs by permitting them to use bus lanes. The study is based on microsimulation road traffic modelling for a designated research area that is part of the transport system impacted by an important traffic generator (a shopping centre) within the city of Łódź in Poland. The application of variables that describe the equilibrium of the transport system during afternoon rush hours makes it possible to determine the impact of EV traffic on the efficiency of the whole system. The simulation also allows the authors to determine the percentage of EVs in the total volume of vehicles at which traffic conditions deteriorate for all or individual groups of road users (internal combustion and hybrid cars, EVs, and public transport). The study can therefore be said to provide wide diagnostic material that facilitates appropriate policy decisions regarding the privileging of EVs that would be more flexible in terms of their changeability in time and space, and would indicate the percentage of EVs for which the incentive may begin to return counterproductive effects, i.e., it may result in the sui generis disruption of other road users and limit the efficiency of public transport—undoubtedly the most fundamental keystone of any policy of sustainable urban mobility. In contrast to numerous studies on the functional aspects of private electric car transport [15-19] — which mainly focus on the distribution of charging points and their adaptation to the functional and spatial structure of the city or the transport needs of the population-our analysis focuses on the role that the growing number of electric vehicles will play in the local transport system. Assuming the aforementioned increase in the independence of vehicles from charging points in urban spaces (for instance, as a result of the increase in battery productivity), it seems justified to carry out research on the impact of electric vehicle traffic with special rights on the transport balance. The results of this type of research can be used to validate the process of implementing the assumptions of the sustainable urban mobility strategy [20]; its most important element is reducing the environmental pressure resulting from the obligatory flows in the city space [21]. The introduction of electrical solutions to power individual transport vehicles is necessary in this respect [22-24]. Measurements of the vehicle traffic structure in the city-taking into account the division into electric vehicles and vehicles with other engines - are very important. The results of such observations provide data on the real share of EVs in traffic flows, and whether it affects the transport balance of the entire system.

\section{Theoretical Foundations}

\subsection{Sustainable Transport}

In 1987, the World Commission on Environment and Development released Our Common Future (also known as the Brundtland Report), in which sustainable development 
was defined as "development that meets the needs of the present without compromising the ability of future generations to meet their own needs" [25]. During the 1992 Rio de Janeiro Earth Summit, the concept of sustainable development was recognised as a one of several fundaments for drafting policies and strategies. The outcome of the Summit was a global action plan for environmental protection called Agenda 21 [26,27], whose objectives were also reflected in the Maastricht Treaty of 1992-which, in the following years, made the idea of sustainable development a major fundament of the European Union, the manifestation of which was the first strategy of sustainable development, launched in $2001[28,29]$.

Any population increase in cities results in a corresponding rise in demand on transport services, which makes public transport systems one of the key components of modern urban life [25,30,31]. Modern cities need efficient and fully operational systems of mass transit in order to guarantee development, economic growth, and a better quality of life for their citizens [31-33].

For over two decades, the direction of transport development in the EU has been designated by common transport policy, the premises of which are released by the European Committee in the so-called green, blue, and white books. EU transport policy covers issues related to urban transport, e.g., the overall strategy for sustainable development, and a new culture of mobility adjusted to global trends and tendencies [34]. The promotion of sustainable transport by EU institutions has created a need to reanalyse the existing solutions, and to develop new ones that are friendlier to the environment and to society [35]. As a result, transport services and infrastructure are requisites for the majority of the goals of both local sustainable development and sustainable development across the whole planet. Although the creation of sustainable transport solutions is one of the greatest challenges faced by cities, it also offers the chance to develop low-emission cities and achieve climate stability $[14,36]$.

\subsection{Sustainable Urban Mobility}

Sustainable transport has become the foundation for the development of the concept of sustainable urban mobility. Many large cities today face challenges related to the mitigation of the negative effects of human activity [37-40]. Sustainable urban mobility requires the transition from conventional models of mobility (private cars running on fossil fuels, and other road transport) to alternative and more sustainable solutions (e.g., EVs, shared vehicle fleets, city bikes, electric scooters, etc.) [14]. Other solutions applied in cities and urban areas to improve mobility include the optimisation of the available modes of transport and the development of more effective combinations (co-modality) of various means of mass transit (e.g., trains, trams, the underground, buses, taxis, etc.) and private transport (e.g., cars, motorbikes, bicycles, walking, etc.) [30,41].

In Poland, transport and environmental policy is generally consistent with European frameworks, and the objectives reflect the state's needs and capabilities. Table 1 presents the strategic documentation that contains references to sustainable urban mobility in the EU, Poland, and the city of Łódź.

The most important document on the management of urban mobility is the Sustainable Urban Mobility Plan (SUMP), which the EU recommends as an effective tool for transport policy. Sustainable urban mobility planning takes into account all types of transport in a city - public and non-public transport, passenger and goods, as well as motorised and unmotorised [14,42-44]. 
Table 1. Documents related to sustainable urban mobility planning in the EU, Poland, and Łódź.

\begin{tabular}{|c|c|c|}
\hline EU Urban Level & National Level (Poland) & National Urban Level/Łódź City \\
\hline $\begin{array}{l}\text { Green Paper on Urban } \\
\text { Mobility (2007) }\end{array}$ & $\begin{array}{c}\text { National Spatial } \\
\text { Development Concept } \\
2030(2013)\end{array}$ & National Urban Policy 2023 (2015) \\
\hline $\begin{array}{c}\text { Leipzig Charter on } \\
\text { Sustainable European } \\
\text { Cities (2007) }\end{array}$ & $\begin{array}{c}\text { Mid-term National } \\
\text { Development Strategy } \\
2020(2012)\end{array}$ & $\begin{array}{c}\text { Sustainable Transport Plan for } \\
\text { Łódź (2018) }\end{array}$ \\
\hline Action Plan on Urban & National Environmental & \\
\hline Mobility (2009) & Policy 2009-2012 (2009) & \\
\hline Urban Mobility & Poland's Energy Policy & \\
\hline Package (2013) & $2030(2009)$ & \\
\hline $\begin{array}{l}\text { Sustainable Urban Mobility } \\
\text { Plans (SUMPs) (2014) }\end{array}$ & $\begin{array}{c}\text { Transport Development } \\
\text { Strategy until } 2020 \text { with a } \\
\text { perspective until } 2030 \text { (2013) }\end{array}$ & \\
\hline The European Green & Public Sustainable Transport & \\
\hline Deal (2019) & Development Plan (2012) & \\
\hline Sustainable and Smart & Strategy of Responsible & \\
\hline \multirow[t]{12}{*}{ Mobility Strategy (2020) } & Development (2017) & \\
\hline & Poland's Electromobility & \\
\hline & Development Plan (2017) & \\
\hline & National Framework for & \\
\hline & Policy of Alternative Fuels & \\
\hline & Infrastructure & \\
\hline & Development (2017) & \\
\hline & Acts Establishing the & \\
\hline & Low-Emission Transport & \\
\hline & Fund (FNT) (2018) & \\
\hline & Act on Electromobility and & \\
\hline & Alternative Fuels (2018) & \\
\hline
\end{tabular}

Source: own elaboration based on $[27,42,43]$.

\subsection{Electromobility and Its Promotion}

\subsubsection{Electromobility}

The simplest way to define electromobility is to describe it in two dimensions: the first refers to using vehicles with an electric powertrain for purposes of mass transit and private transport, while the second involves the infrastructure dedicated to EVs. According to Johansen [45], future electromobility will supersede and replace energy obtained from conventional sources, and Higueras-Castillo et al. [46] predict that electricity-as an alternative source of energy-will be applied on a massive scale, greatly contributing to the development of sustainable mobility, the main purpose of which is to reduce the number of vehicles with conventional drivetrains - especially in urban areas-and, in consequence, to mitigate any negative effects on residents' health and the environment [47].

The positive impact of EVs on different aspects of the environment has been discussed by numerous researchers from all over the world [48-51], and the development of electromobility is the subject of a large number of multidimensional studies on the matter.

Firstly, there is a study by Strak et al. [52], who delve into the potential and possible applications of electromobility. Another study on the development and implementation of electromobility was conducted by Shafiei et al. [53], who took into account both its technical and economic (cost-related) aspects; they performed a simulation that involved a proposed change in taxation - tax rebates for EVs, accompanied by a ban on selling cars with diesel engines.

Another noteworthy publication is that by Schrickama et al. [54], which focuses on the potential ratio of electromobility. The authors found a ratio that would optimise the potential of the sustainable and appropriate introduction of EVs in large urban agglomerations.

The scientific literature on the subject also consists of several studies that focus on the political instruments used by governments worldwide to popularise EVs and encourage 
their use, including works by Ryghaug and Skjølsvold [55], Nanaki et al. [56], Bühne et al. [57], and Sendek-Matysiak [58].

As for studies that focus on Poland specifically, the development of electromobility and its legal framework was analysed by Tucki et al. [59], Dróżdż and Starzyński [60], and Sendek-Matysiak [58]. Furthermore, the literature on electromobility in Poland encompasses such issues as environmental pollution, the current scale of electromobility, and the stimulants behind the sector's development, as discussed by Kłos et al. [61], Kupczyk et al. [62], Połom et al. [63], etc.

\subsubsection{Promotion}

Despite its relatively long history, transport-related electromobility still remains a market innovation [59]. Ongoing societal development contributes directly to the increase in car use, which — as stressed by Kousoulidou et al. [64] — has become a major source of environmental pollution, i.e., the main emitter of air pollutants. On top of that, the total number of cars is growing far more dynamically than the global population, especially in Europe [59].

According to Zhou et al. [65], the premises and promotional endeavours related to the implementation of electromobility that different countries undertake can be divided into three classes: the first is connected with research into power systems and electrification; the second includes EV-related incentives for potential customers (miscellaneous benefits and privileges that make the daily use of EVs more convenient); and, finally, investments in electromobility infrastructure. Examples of these initiatives can be seen in the US, China, and EU member states, including Poland.

In the US, the first noticeable incentivisation for the popularisation and development of electromobility was the American Recovery and Reinvestment Act of 2009 (ARRA) [66], which paid special attention to the use of alternative fuels, and innovative and technologically advanced vehicles. According to Leurent and Windisch [67], other important and illustrative examples of how electromobility has been supported and promoted in the US include:

- The Qualified Plug-in Electric Drive Motor Vehicle Tax Credit of between USD 2500 and 7500, depending on the battery capacity and the kerb weight of the purchased vehicle;

- investment tax credit for alternative fuel infrastructure and installation of charging stations-reimbursement of up to $50 \%$ of the costs incurred by businesses, and up to USD 2000 for private consumers; and

- USD three billion on low-emission vehicles for governmental administration.

A key player in the automotive industry is China, where electromobility took centre stage in 2008, when the New Energy Vehicle (NEV) programme was initiated, involving the replacement of old vehicles with EVs-the main objective of which was to produce 500,000 new EVs by 2011, with EVs expected to amount to 5\% of total annual sales of new cars [68].

Electromobility is also a crucial field of development in European countries [59,69,70].

The list of incentives and promotional initiatives undertaken by individual member states is long (Table 2), and these may be financial (e.g., direct EV subsidies, various vehicle taxation classes, free parking, etc.) or non-financial (e.g., access to HOV- and EV-only lanes, low- and zero-emission zones in city centres, etc.) [71]. 
Table 2. Benefits, incentives, and privileges for EVs in different European countries.

\begin{tabular}{cc}
\hline Type & Country \\
\hline \multirow{2}{*}{ Subsidies } & $\begin{array}{c}\text { Austria, Finland, France, Ireland, Malta, Germany, Portugal, } \\
\text { Romania, Slovenia, Sweden, United Kingdom, Belgium }\end{array}$ \\
\hline \multirow{2}{*}{ Road tax exemptions } & $\begin{array}{c}\text { Austria, Bulgaria, Czech Republic, Greece, Netherlands, Latvia, } \\
\text { Romania, Slovakia, Sweden, Hungary, United Kingdom, }\end{array}$ \\
\cline { 2 - 3 } Free vehicle registration & $\begin{array}{c}\text { partially: Belgium, Cyprus, Denmark, Spain, Ireland, } \\
\text { Luxembourg, Malta, Germany, Norway, Slovenia, } \\
\text { Switzerland, Italy }\end{array}$ \\
\cline { 2 - 3 } & $\begin{array}{c}\text { Austria, Cyprus, Greece, Netherlands, Luxembourg, Latvia, } \\
\text { Portugal, Romania, Hungary, United Kingdom, }\end{array}$ \\
\cline { 2 - 3 } Non-financial incentives & $\begin{array}{c}\text { partially: Belgium, Croatia, Denmark, Finland, France, Malta, } \\
\text { Norway, Slovakia, Slovenia, Switzerland }\end{array}$ \\
& Austria, Denmark, France, Spain, Ireland, Lithuania, Latvia, \\
& $\begin{array}{c}\text { Germany, Norway, Poland, Portugal, Slovakia, Slovenia, Sweden, } \\
\text { Hungary, United Kingdom, Italy }\end{array}$ \\
\hline Source: own elaboration based on [59]. &
\end{tabular}

The incentives and benefits offered and listed in the documentation are mainly financial. An incentive for Polish drivers is the programme called Green Car, dedicated to citizens wishing to purchase a more eco-friendly car. The subsidies amount to PLN 37,500 for an EV with a price limit of PLN 125,000; and PLN 90,000 for a vehicle powered by hydrogen fuel cells with a top price of up to PLN 300,000. The programme will continue until 2027 [72]. Additionally, non-financial incentives for EV users include free access to bus lanes by 2026, and no payment in all public parking zones [73].

Out of all of the charging points across Europe, as few as $0.2 \%$ are located in Poland. In 2020, the average monthly growth rate of the charging network amounted to $2 \%$, and as of the end of June 2020, Poland had just 1194 public EV charging stations (2258 points) [74].

\subsection{Polish EV Vehicle Numbers vs. the European and Worldwide Background}

When the development of electromobility products and services is analysed globally and regionally, it must be stated that electromobility is becoming an increasingly more dynamic trend $[75,76]$. Now seen as a key component in reducing emissions and energy consumption in the mobility sector [77], electric vehicles-also known as ECVs (electrically chargeable vehicles) - were, in fact, first launched in 1834. At that time, such vehicles were mostly produced in the US, Great Britain, and France-especially in the last decade of the 19th century [78].

Today, EVs can be divided into several classes, which differ in the technical specifications of their power unit: The first type is battery electric vehicles (BEVs), which have no internal combustion engine and are powered by traction batteries to be charged from external sources. A typical feature (and a major drawback) of these cars is their limited driving range, which practically makes them applicable only in urban situations [79]. At the same time, it should be noted that there are more and more BEV models on the market, which are able to achieve comparable performance with conventional vehicles. However, their availability is significantly limited due to, inter alia, their price [80]. The second class is hybrid electric vehicles (HEVs), also known as full hybrids, which are powered by internal combustion engines and batteries [81]. A subclass of HEVs is plug-in hybrid electric vehicles (PHEVs), which are also hybrids, but with batteries that can be charged from an external source, i.e., via a charger. Another major class of EVs is extended-range electric vehicles (EREVs), which are structurally similar to hybrids, but differ in terms of their powertrain setup [82]. Finally, there is a class of cars that uses fuel cells instead of, or together with, batteries, i.e., hydrogen electric cars, also known as fuel cell electric vehicles (FCEVs). In FCEVs, the electric motor is powered by fuel cells that generate energy from the reaction between oxygen and hydrogen [83]. 
Analyses of and forecasts for electric power technology predict further and dynamic growth of EV sales [84]. However, Liebreich [85] argues that EVs will not have a significant impact on road transport before 2040, when BEVs and PHEVs are expected to outnumber conventionally powered cars, while Robecosam [86] claims that a complete transition from internal combustion car to all-electric vehicle will be possible only by 2050 .

According to the European Automobile Manufacturers Association (ACEA), 3\% of all passenger cars sold in Europe in 2019 had an electric powertrain, which means that there was a significant rise in EVs when compared to 2014 (+2.4 p.p.). For HEVs, the increase was even higher (+4.5 p.p.), and amounted to $5.9 \%$ of all new cars purchased in the EU. On the other hand, the smallest share (of the total car sales in the EU) was recorded for FCEVs- $0.04 \%$ (Polish Automotive Industry Association). The data from ACEA explicitly show the dominant position of Germany and United Kingdom when it comes to the total number of EVs (Table 3).

Table 3. Diversification of EVs' numbers and market share in the European states.

\begin{tabular}{cccc}
\hline Electrically Chargeable Vehicles (ECVs) & Country & No. of Units & Market Share (\%) \\
\hline \multirow{2}{*}{ Countries with the highest sales } & Germany & 108,629 & 3 \\
& United Kingdom & 72,766 & 3.1 \\
Netherlands & 66,801 & 15 \\
Countries with the lowest sales & Estonia & 97 & 0.3 \\
& Latvia & 102 & 0.5 \\
\hline Hybrid electric vehicles (HEVs) & Country & No. of units & Market share (\%) \\
\hline & Germany & 193,902 & 6.4 \\
Countries with the highest sales & United Kingdom & 156,178 & 5.7 \\
& Italy & 109,789 & 7.5 \\
Countries with the lowest sales & Latvia & 1468 & 4.8 \\
\hline Fuel cell electric vehicles (FCEVs) & Bulgaria & 1975 & Market share (\%) \\
\hline & Country & No. of units & 0 \\
Countries with the highest sales & Germany & 210 & 0 \\
& Netherlands & 156 & 0
\end{tabular}

Source: own elaboration based on [72].

\section{The Research Area}

\subsection{Selected Features of the Transport System and Socio-Economic Standing}

Accessibility can be managed on a micro- or macroscopic scale. The scale of the city/agglomeration/region may involve management of accessibility for all users and transport systems, for selected groups of users and their activities, for chosen trip motivations (e.g., retail, services, recreation, etc.), or for particular facilities that are massive traffic generators (e.g., major employers, shopping malls, etc.) [87]. This paper focuses on the management of accessibility in reference to visits to a shopping centre-namely, the E. Leclerc shopping centre in Łódź.

The number and distribution of residents are the most important factors that impact time, location, and directions of transport needs. Łódź has 696,503 citizens, and the city's population density is shaped by two axes, running from north to south, and from east to west.

The transport layout in Łódź takes the shape of a grid (a framework layout) in the city centre, which becomes gradually less regular the farther out one goes. The system of roads for international, national, and regional connections is shaped by a section of the A1 motorway in the eastern part of Łódź, four national roads, and two regional roads that run through the city [88-90]. The researched area is located in the north of Łódź, in the vicinity of a national road that is part of the city's framework transport system (Figure 1). 
^

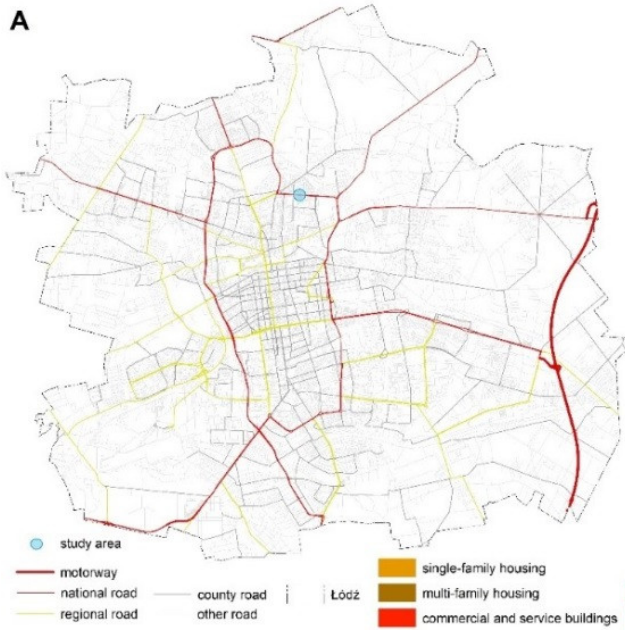

B

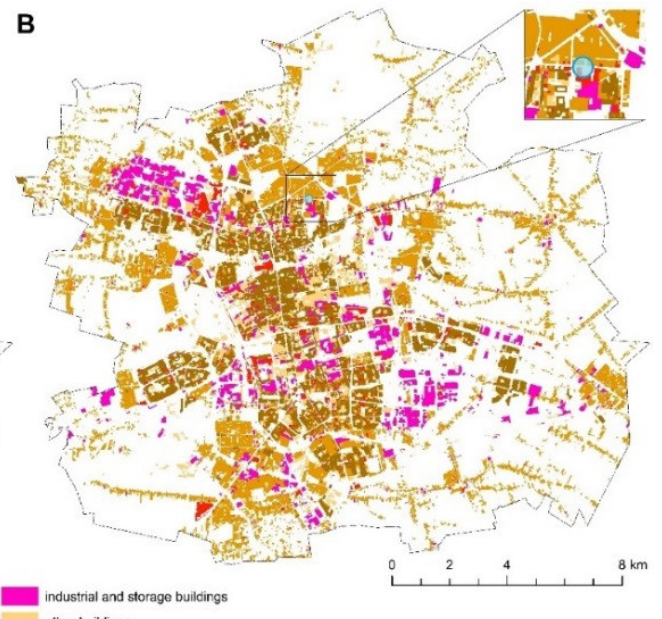

Figure 1. The location of the researched area against the background of the road network (A) and built-up areas in Łódź (B). Source: own elaboration based on the Database of Topographic Objects and OpenStreetMap.

Since the major traffic routes that run through Łódź are crucial for the national road transport, and the city itself is the only large agglomeration in the region, surrounded by numerous smaller towns and settlements, a high density of (mainly) commuter traffic is recorded in the city, which refers in particular to roads that form its arterial routes. Less dense traffic is observed at the weekends, when higher density is recorded only in the south (Aleja Piłsudskiego), west (national road \#91), and in the northern section of national road \#14, where it runs within the administrative boundaries of Łódź (Figure 2).

As of 11 March 2021, Łódź had 82 bus and 21 tram lines. The area under analysis was serviced exclusively by buses (one night and four day lines), with the highest bus frequency in the area corresponding with the morning and afternoon rush hours (Figure 3).

The E. Leclerc shopping centre is located outside the city centre, in a one-storey building with an adjacent car park that separates it from its surroundings. The total parking area around the researched facility amounts to $48,036 \mathrm{~m}^{2}-39 \%$ of which is occupied by Leclerc, whose car park provides space for a maximum of 800 cars. The building houses a hypermarket and a shopping arcade with stores and service outlets (the total space is 13,000 $\mathrm{m}^{2}$, including $7000 \mathrm{~m}^{2}$ of retail space). The venue is open Monday to Saturday, from 7 a.m. to 9 p.m., and on trading Sundays - between 10 a.m. and 7 p.m. When compared to other shopping centres in Łódź, the E. Leclerc shopping centre has poor transport accessibility for trips taken on foot and by public transport, average accessibility for cyclists, and very good accessibility for car users [91], which makes it a particularly attractive destination for the latter. Customer traffic is mainly generated by the hypermarket itself (the anchor store of the shopping centre), which offers a comprehensive range of fast-moving consumer goods, which spurs visitors to make extensive purchases, thereby necessitating the use of a car.

A major factor that impacts the changeability is the bill on retail restrictions on Sundays and public holidays (as well as some certain other days) that was introduced in Poland in March 2018. Since 2020, the ban has affected all but seven Sundays (three Sundays preceding the most important Christian holidays, the last Sundays of January, April, June, and August and, exceptionally, one more Sunday in December 2020 due to the COVID-19 pandemic) $[92,93]$. As shown in Figure 4, a higher traffic density at intersections within the analysed area is recorded mainly on Mondays, Tuesdays, Wednesdays, and Saturdays in weeks preceding non-trading Sundays (compared to weeks preceding trading Sundays). On the other hand, the greatest drop in vehicle numbers on the same intersections is recorded on non-trading Sundays when compared to trading Sundays. 

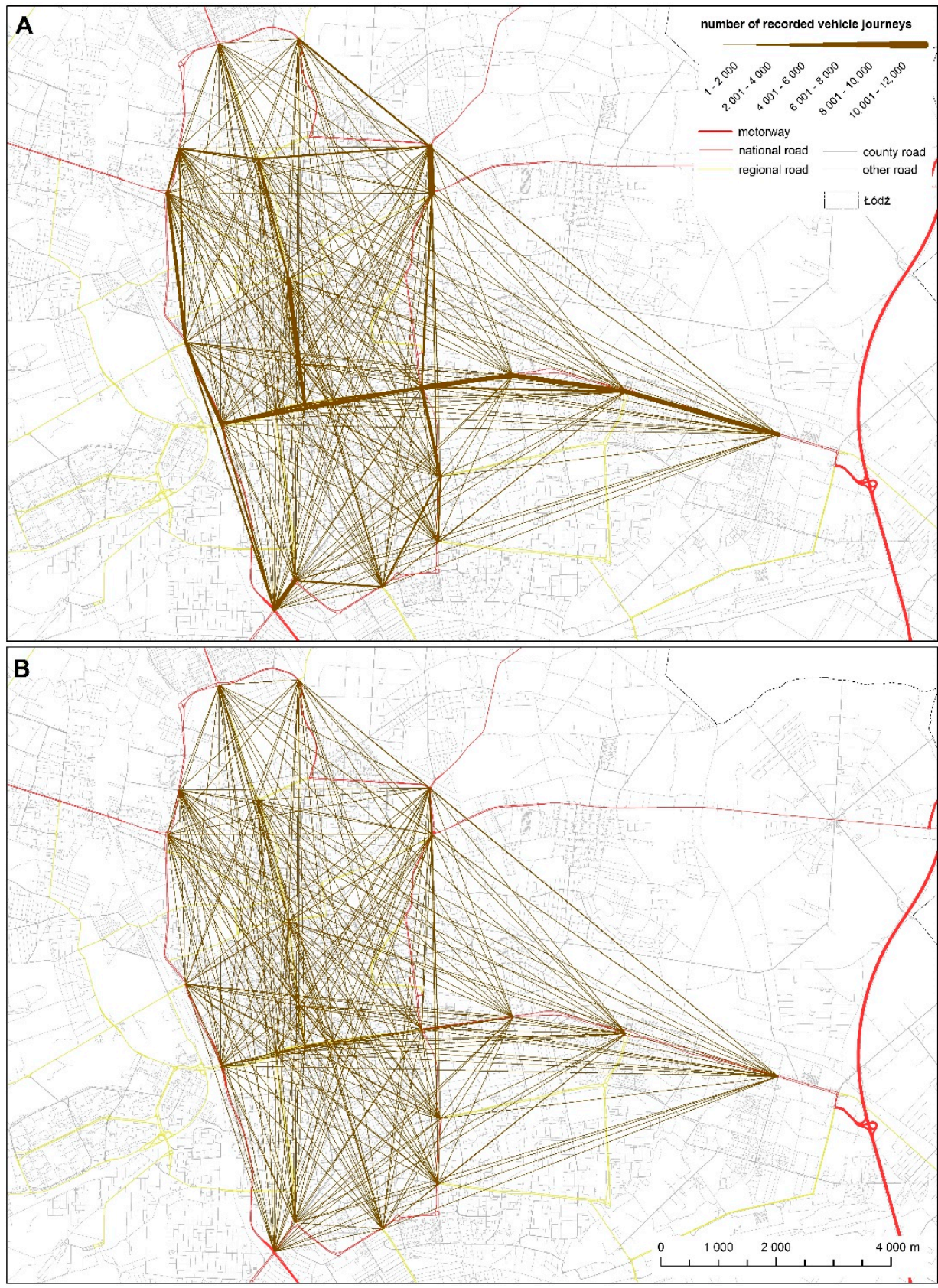

Figure 2. The average number of trips between the selected nodes of the Łódź road network during afternoon rush hours from Tuesday to Thursday (A) and at weekends (B). Source: own elaboration based on the Database of Topographic Objects, OpenStreetMap, and the ANPR data collected by the ITS in Łódź. 


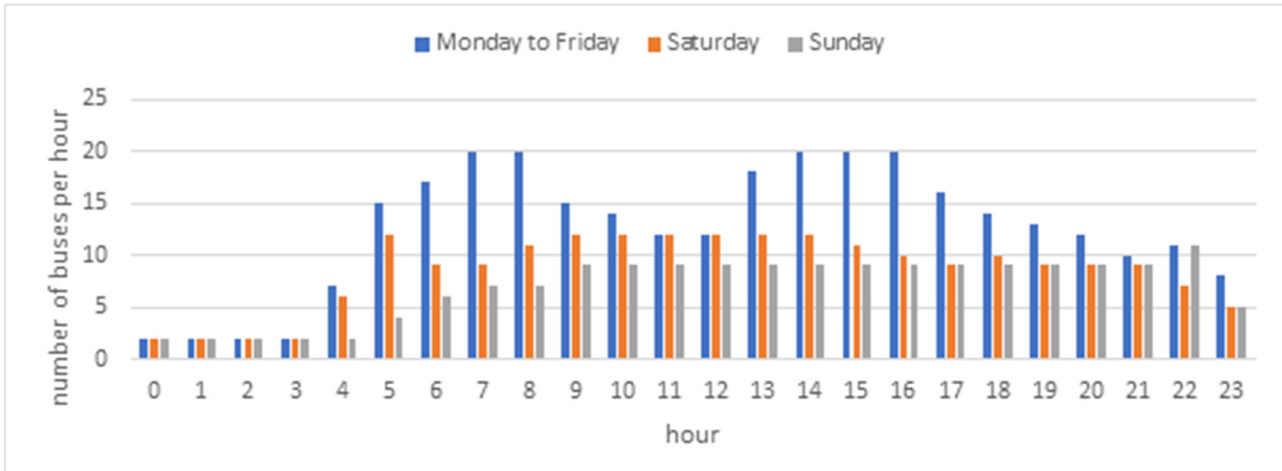

Figure 3. Local bus frequency in the analysed section of the road network. Source: own elaboration based on MPK-Łódź timetables.

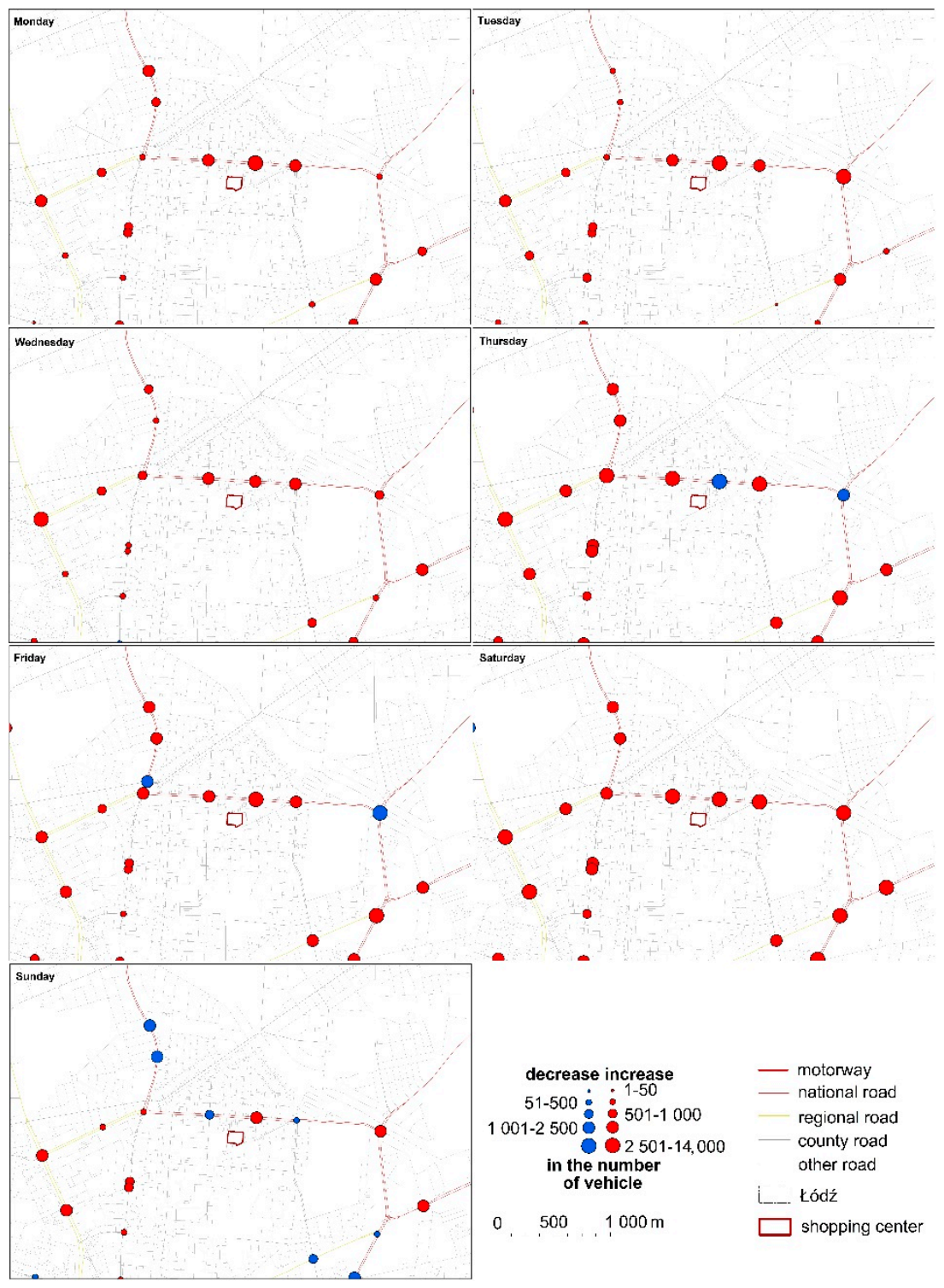

Figure 4. The average change in the number of vehicles at intersections within the researched section and its immediate vicinity between weeks with a trading and non-trading Sunday. Source: own elaboration based on the Database of Topographic Objects, OpenStreetMap, and data collected by the induction loops of the ITS in Łódź. 
Significant differences can also be observed from the analysis of hourly traffic density for individual days of the week when a division into trading and non-trading Sundays is applied. The highest density of incoming and outgoing traffic to/from the shopping centre is recorded during the so-called afternoon retail peak, following the afternoon rush hour. For those weeks preceding non-trading Sundays, higher traffic density is recorded on Mondays - especially during early and late morning hours-when compared to Mondays preceding trading Sundays, whereas Thursday afternoons in a week before a trading Sunday are much busier (in terms of traffic density) when compared to the same day of the week before a non-trading Sunday. At the weekends, traffic at intersections in the vicinity of the analysed shopping centre is highest around noon and in the afternoon hours and, naturally, noticeable primarily on Saturdays preceding a non-trading Sunday, and on trading Sundays (Figure 5).

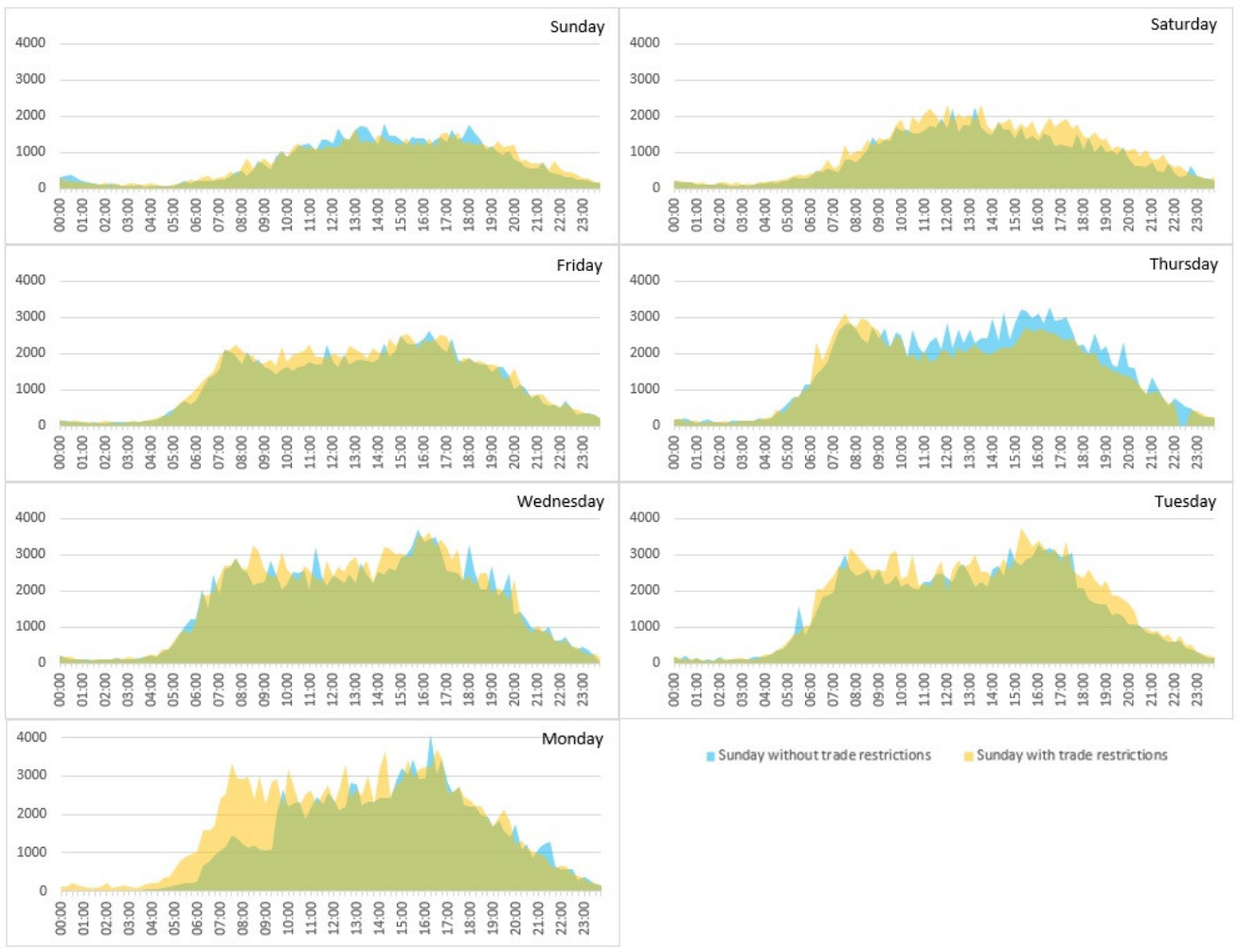

Figure 5. Temporal differentiation of the average vehicle traffic density at the analysed intersections, with the applied division into weeks with and without non-trading Sundays. Vertical axis: number of vehicles; horizontal axis: hour. Source: own elaboration based on data from induction loops of the ITS in Łódź.

This stems from the fact that the area is located in the vicinity of a road that constitutes a part of the city's framework transport layout, and also because of the spatio-functional structure around the shopping centre itself. The E. Leclerc shopping centre is located close to private houses, blocks of flats, and service outlets (whose presence in the area may, to a varied extent, be related to the presence of the shopping centre) [94], which are additional traffic generators in the area (Figure 6).

\subsection{Local Transport and Automotive Policy}

In 2019, car ownership in Łódź amounted to 605.4 (the number of vehicles per 100 inhabitants, according to the Polish Central Statistical Office), while the total number of registered vehicles was 488,055 - of which $84 \%$ were passenger cars, $11 \%$ lorries, $4.7 \%$ motorbikes, and $0.3 \%$ buses. Among these vehicles, only 344 private passenger cars and 11 buses had an electric powertrain (although the city is taking steps to expand the electric 
bus fleet). Furthermore, there were plans to install 200 charging points in 29 locations across Łódź by 2020 (Łódź City Hall).

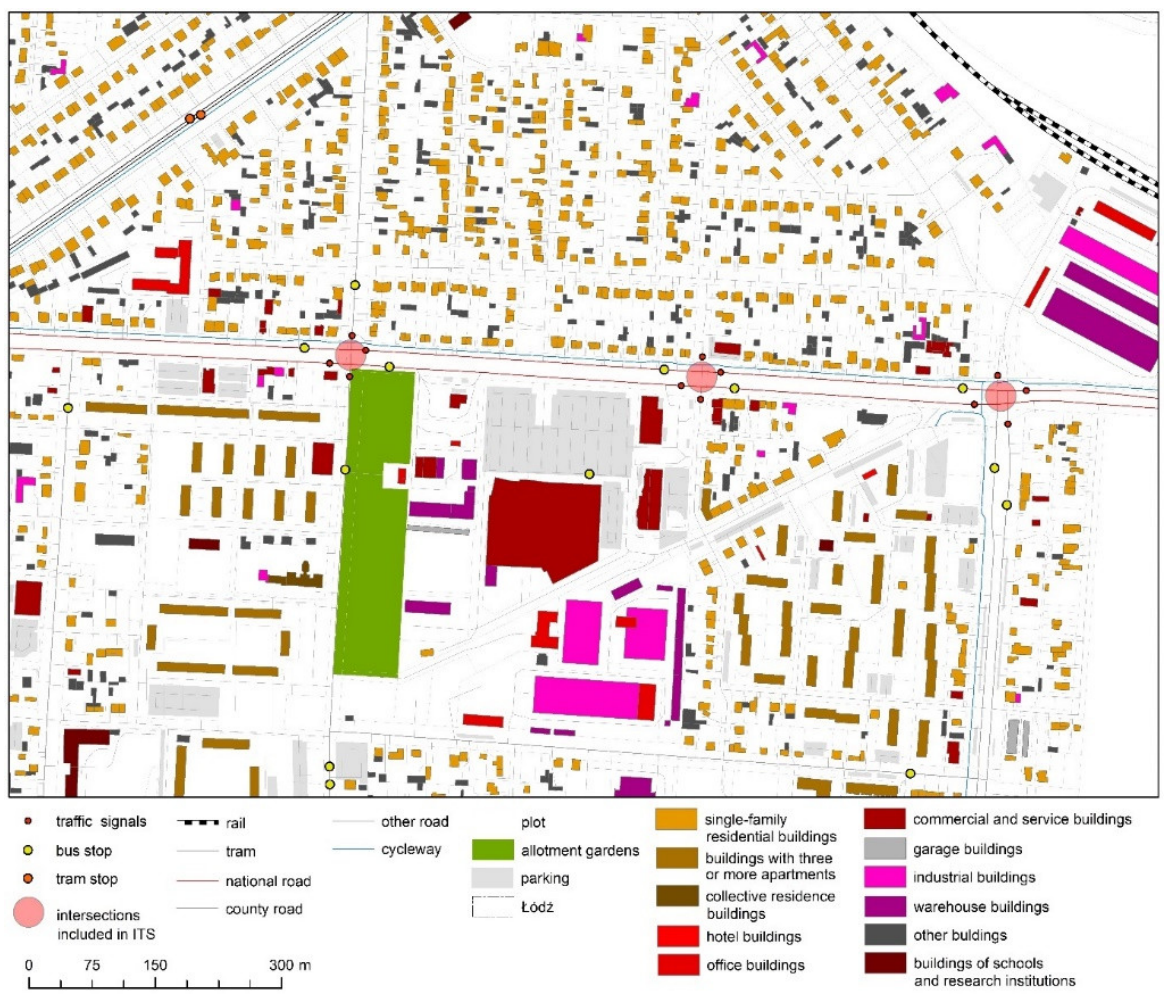

Figure 6. Selected elements of the transport infrastructure and functional differentiation of built-up areas in the vicinity of the researched area. Source: own elaboration based on the Database of Topographic Objects and OpenStreetMap.

According to the document entitled Transport Policy for the City of Łódź [95], the main purpose of the city's transport policy is the transformation and development of the transport system so that it becomes as safe and efficient as possible; in this document, the city was divided into three zones, which were attributed with different priorities: Zone I is the city centre, where the predominant role is preserved for pedestrian traffic and mass transit, accompanied by a substantial reduction (and sometimes even complete elimination) of private car traffic. Zone II is a densely built-up area where more freedom is offered to private car users, although mass transit is still privileged. In Zone III, which consists of the peripheral areas, the road layout is adjusted more to the needs of private car use, while still guaranteeing high-quality mass transit connections to the city centre. To achieve the implementation of the transport policy, the city authorities have applied various solutions, as partially presented in Table 4 .

Currently, the city has entered a key phase in its vital (and huge) development investments in public transport, e.g., the construction of the train station in the city centre (Śródmieście Station) and the cross-city railway tunnel being built as part of the 15-Minute City Programme. The local authorities expect that upon the completion of the tunnel, a journey across the city (along the east-west axis, Łódź Kaliska Station-Łódź Widzew, and Łódź Żabieniec-Łódź Widzew) will take 15 min (Łódź City Hall). 
Table 4. Selected solutions applied to implement the transport policy in Łódź.

\begin{tabular}{|c|c|}
\hline & Goals of the Transport Policy \\
\hline $\begin{array}{l}\text { Related to city planning and } \\
\text { development }\end{array}$ & $\begin{array}{l}\text { Stimulating mixed development of workplaces, services, and } \\
\text { housing by putting areas with different purposes close by; } \\
\text { introducing a new parking policy; } \\
\text { identifying and earmarking locations for a park and ride scheme }\end{array}$ \\
\hline Related to mass transit & $\begin{array}{l}\text { Reinstating trams as the leading mode of transport; overhaul of } \\
\text { selected sections of tram network; } \\
\text { upgrading bus fleet and introduction of bus lanes on the main } \\
\text { traffic routes }\end{array}$ \\
\hline $\begin{array}{l}\text { Related to the road network } \\
\text { and traffic management }\end{array}$ & $\begin{array}{l}\text { Road and bridge maintenance to prevent further deterioration; } \\
\text { traffic restrictions for lorries in the city centre and selected } \\
\text { housing estates; } \\
\text { temporal traffic restrictions for heavy traffic (lorries and delivery } \\
\text { vans) on selected routes and in selected areas }\end{array}$ \\
\hline Related to parking & $\begin{array}{l}\text { Zone I-new multi-storey car parks; } \\
\text { Zone II-new car parks in the vicinity of mass transit stops } \\
\text { (including those of the park and ride scheme) }\end{array}$ \\
\hline $\begin{array}{l}\text { Related to environmental } \\
\text { protection }\end{array}$ & $\begin{array}{l}\text { Higher frequency and greater efficiency of road checks conducted } \\
\text { by the police and city guards }\end{array}$ \\
\hline
\end{tabular}

\section{Materials, Methods, and Limitations}

\subsection{Materials and Methods}

This study is based on two important sources of data: The first is information on infrastructure and traffic management; in order to develop a microsimulation model, the authors conducted a field inventory (of land use, etc.) and a review of the relevant technical documentation obtained from the local roads authority. As a result, it was possible to accurately reflect the transport infrastructure (its location and dimensions, i.e., the width of carriageways and lanes) and the applied principles of traffic management (right of way, traffic light cycles, etc.) (Figure 7). The second type of data contained information on recorded loads on the road network and traffic volumes generated by the shopping centre in question. Times and frequency of bus services were obtained from the local public transport operator (MPK-Łódź), while the values of loads on intersections were the results of empirical measurements taken from the induction loops (part of the ITS) that are installed on each lane within every single intersection that was analysed in this study (Figure 6) [88]. The data from the loops are from 16 March 2018 (Friday), taken between 4 p.m. and 5 p.m. in 15-min intervals. The ITS dataset was expanded with manual measurements taken for the only large traffic generator that has entrances and exits onto the analysed section of the network (the shopping centre). The measurements were conducted in 15-min intervals (for the purposes of the study, the authors used results from the period between 4 p.m. and 5 p.m. on Friday) (Figure 7).

Two generators were added for each entrance to the analysed section of the network and attributed with traffic volumes returned by the detectors-and in the case of the exits from the shopping centre, also with data obtained via manual measurements. Next, maps of the traffic structure were developed and calibrated using data from the detectors located at access points (i.e., entrances to and exits from all intersections) within the analysed network, and on the first intersection outside the analysed network. The aforementioned infrastructure (the model of the applied network) and maps of the traffic structure were later used to develop a microsimulation model of traffic, built with PTV Vissim software. 


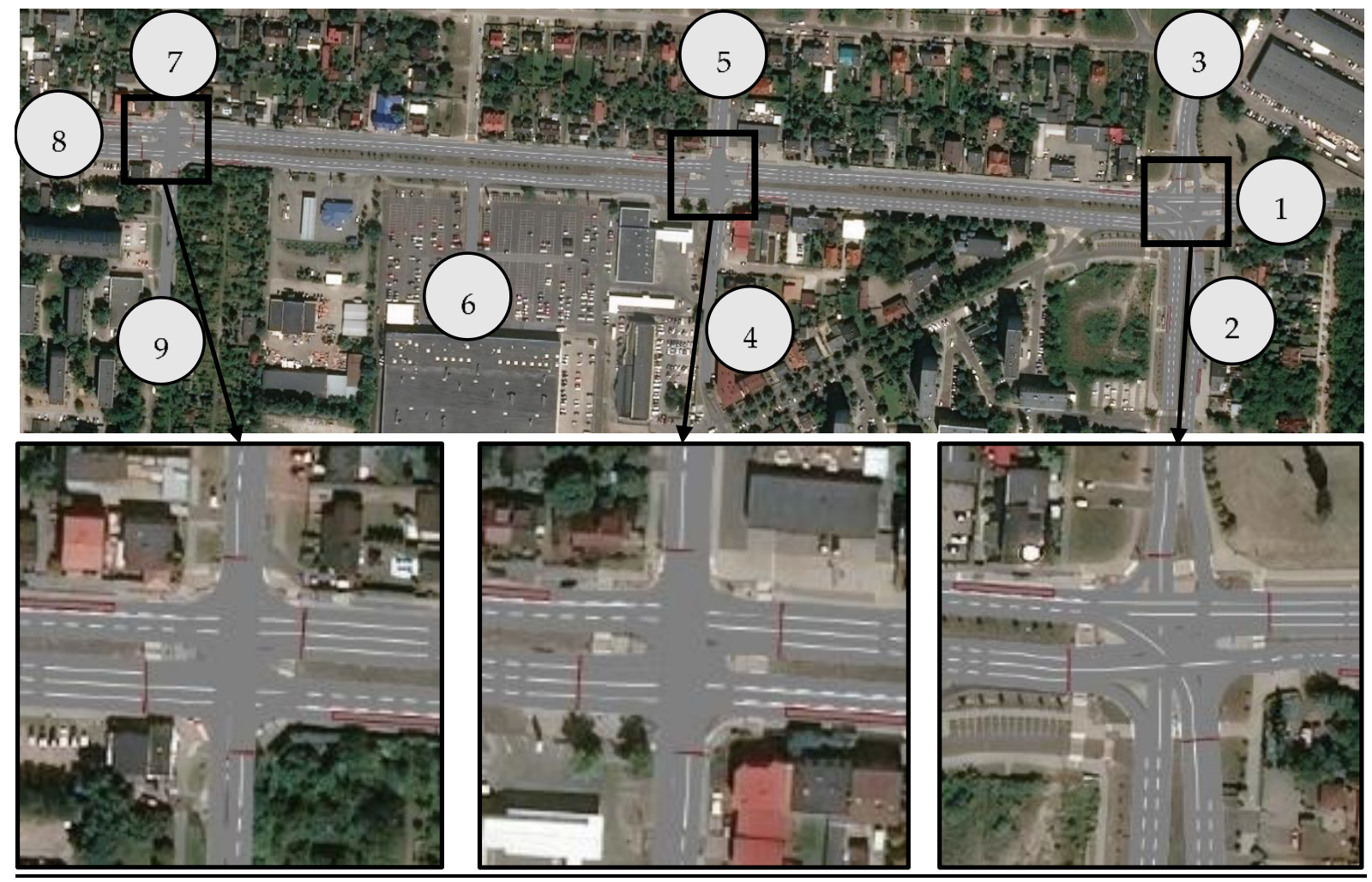

\begin{tabular}{|c|c|c|c|c|c|c|c|}
\hline \multirow{2}{*}{$\begin{array}{l}\text { Entrance } \\
\text { Number }\end{array}$} & \multirow[t]{2}{*}{ Direction } & \multicolumn{4}{|c|}{$\begin{array}{l}\text { No. of Vehicles during Individual Intervals for } \\
\text { Specified Access Points }\end{array}$} & \multicolumn{2}{|c|}{ Total No. of Vehicles } \\
\hline & & 4:00-4:15 p.m. & 4:15-4:30 p.m. & 4:30-4:45 p.m. & 4:45-5:00 p.m. & On Exit & On Entrance \\
\hline \multirow{3}{*}{1} & $2+\leftarrow$ BUS & 24 & 12 & 23 & 8 & 67 & \multirow{3}{*}{838} \\
\hline & $\leftarrow$ & 223 & 184 & 168 & 134 & 709 & \\
\hline & $\Gamma$ & 24 & 20 & 9 & 9 & 62 & \\
\hline \multirow[b]{2}{*}{2} & $\uparrow$ & 39 & 40 & 32 & 37 & 148 & \multirow{2}{*}{314} \\
\hline & 7 & 42 & 50 & 41 & 33 & 166 & \\
\hline \multirow{2}{*}{3} & 5 & 11 & 11 & 15 & 12 & 49 & \multirow{2}{*}{104} \\
\hline & $\downarrow$ & 17 & 16 & 11 & 11 & 55 & \\
\hline \multirow{2}{*}{4} & $f=$ & 28 & 25 & 25 & 25 & 103 & \multirow{2}{*}{207} \\
\hline & 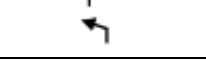 & 28 & 32 & 27 & 17 & 104 & \\
\hline \multirow{2}{*}{5} & $\downarrow$ & 8 & 6 & 5 & 3 & 22 & \multirow{2}{*}{59} \\
\hline & 4 & 9 & 11 & 8 & 9 & 37 & \\
\hline 6 & $\pi$ & 50 & 57 & 59 & 43 & 209 & 209 \\
\hline \multirow[b]{2}{*}{7} & $-\downarrow$ & 32 & 16 & 27 & 31 & 106 & \multirow{2}{*}{172} \\
\hline & 4 & 13 & 18 & 11 & 24 & 66 & \\
\hline \multirow{3}{*}{8} & $\eta_{+} \rightarrow$ BUS & 39 & 44 & 31 & 35 & 149 & \multirow{3}{*}{1207} \\
\hline & $\rightarrow$ & 278 & 250 & 189 & 198 & 915 & \\
\hline & $A$ & 58 & 32 & 21 & 32 & 143 & \\
\hline \multirow[b]{2}{*}{9} & 4 & 37 & 38 & 32 & 38 & 145 & \multirow{2}{*}{250} \\
\hline & $\pi$ & 29 & 28 & 19 & 29 & 105 & \\
\hline
\end{tabular}

Figure 7. Model of the applied network and the number of vehicles for individual entrances.

The authors utilised the Wiedemann-74 car-following model for the applied traffic structure, which was divided into bus, car, and HGV. For the first group, the model determined the time when a given bus appeared within the analysed part of the network, based on the timetable details provided. During the field inventory, it was established 
that the percentage of HGVs in the total number of vehicles (excluding buses) amounted to $2 \%$. The remaining traffic monitored by the induction loops was car traffic. On the basis of these premises, a 10-min simulation was conducted and later used as a base variant for comparison with subsequently simulated scenarios. Each successive simulation was performed on the basis of identical boundary and baseline conditions, with just one difference. The percentage of cars was recalculated afresh following the addition of a new type of vehicle-BEVs. The growth in the share of BEVs depended on the applied scenario (Table 5), with a proportional decrease in the percentage of cars.

Table 5. Scenarios applied in microsimulations.

\begin{tabular}{ccccccccccccccccc}
\hline & I & II & IV & V & VI & VII & VIII & IX & X & XI & XII & XIII & XIV & XV & XVI & XVII \\
\hline $\begin{array}{c}\text { Percentage of BEVs } \\
\text { in the total volume } \\
\text { of cars }\end{array}$ & $0 \%$ & real & $1 \%$ & $2 \%$ & $3 \%$ & $4 \%$ & $5 \%$ & $7.5 \%$ & $10 \%$ & $15 \%$ & $20 \%$ & $30 \%$ & $40 \%$ & $50 \%$ & $75 \%$ & $100 \%$ \\
\hline
\end{tabular}

In scenario 1 -which did not differentiate between various types of cars-the authors applied a base variant in which BEVs were not granted the privilege of using bus lanes. However, each subsequent simulation took this incentive into account. In scenario II, the share of BEVs in the traffic in the analysed section of the network reflected the actual percentage of BEVs in the total number of cars on Łódź roads (approx. $0.8 \%$ ). For the applied time horizon and loads recorded on the network, the model did not show any BEV traffic. In consequence, the results of the simulations in scenarios I and II were identical. Each simulation was observed in the resolution of $0.1 \mathrm{~s}$.

The following average measures were applied for the comparative analysis of scenarios: difference between optimal driving time, duration of the state "in queue" of the vehicle, and frequency of changes to the state "in queue". Additionally, dynamic analyses of the aforementioned measures were conducted for public transport. Deceleration to $5 \mathrm{~km} / \mathrm{h}$ was nominated as the beginning of the queue, while its end was assumed once this speed was re-exceeded.

\subsection{Limitations}

The conducted analysis is associated with a certain group of limitations. At the beginning, it should be noted that due to the relatively high redundancy of the analysed network and its bus lanes (especially when the bus service was infrequent), the presence of privileged EVs hardly impacted driving times. The analysis presented in this paper must not be interpreted universally, since microscale simulations can only be applied for the area in which they were conducted-or other areas of very similar conditions and infrastructure. For the area researched in this study, the authors assumed that reserving bus lanes only for rather infrequent mass transit is not justified when the high redundancy of the network is taken into account. In such locations, granting BEVs access to bus lanes has no significant impact on bus traffic. The impact on the remaining urban traffic there is initially only negative, and once a certain threshold of BEV share (over $10 \%$ of all cars) is crossed, it begins to have a more positive influence, which primarily stems from the peculiar nature of the local transport infrastructure in the researched area. In addition, it should be noted that since it focuses on short journeys to a shopping centre, the study presented in this paper does not take into account the issue of the charging infrastructure, as this factor is of no significance here, which is another shortcoming of the analysis carried out.

\section{Results and Discussion}

According to Daina et al. [84] and their classification of research on traffic modelling and electromobility, the study presented herein is a short-term analysis to evaluate, assess, 
and determine whether the load related to EVs may generate congestion in the distribution network (here: the network of mass transit).

In our simulation, a total of 496 vehicles appeared on the network within $10 \mathrm{~min}$. The analysis in each simulation variant did not show any significant changes in the average value of delay when compared to the theoretical travel time (Figure 8).

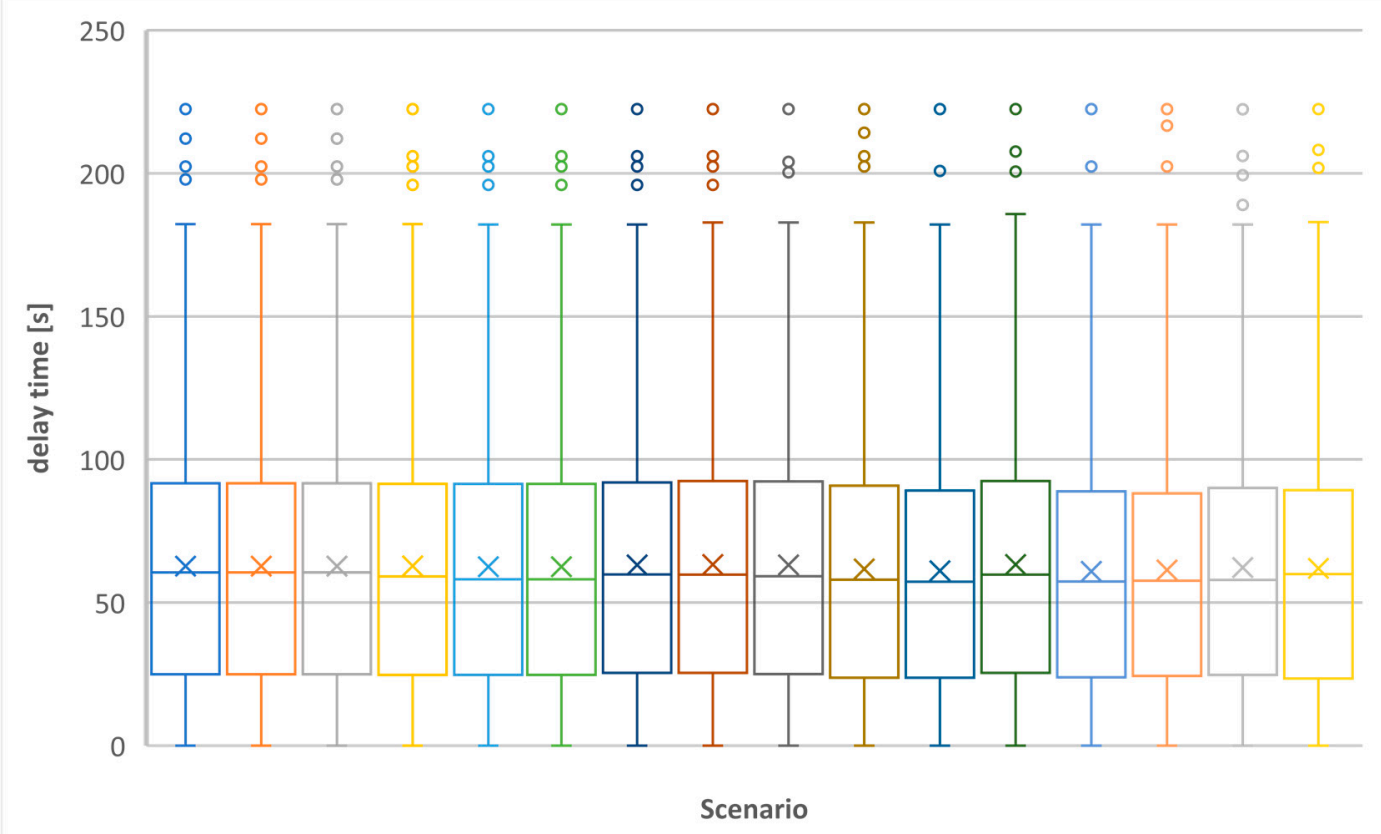

Figure 8. Positional measures and the average $(\mathrm{x})$ difference between optimal driving times for the total number of vehicles on the network in each simulation scenario.

When the base variant was compared with other scenarios, the greatest changes of the analysed parameters were observed for BEVs and other cars (Table 6). However, interpretation of values up to $15 \%$ of $\mathrm{BEVs}^{\prime}$ traffic share is impossible due to the potentially anecdotal nature of the analysed phenomena. A growth in BEVs' share within the total volume of cars improves road conditions for all vehicles, which generally stems from an increase in the network capacity, resulting from a rise in the available space (i.e., use of the bus lane by an increasing number of privileged vehicles). The presence of privileged BEVs in the first simulation scenarios (up to $2 \%$ BEVs within the total number of cars) actually increased driving time on the remaining lanes for other car users, despite the fact that BEVs could use the bus lane and the road space increased. This stemmed from the fact that each bus lane near intersections is also a lane for turning right, and when BEVs used it to go straight across the intersection the lane was blocked for those road users who would otherwise be able to turn right as long as the traffic lights allowed them to. While privileging BEVs for the analysed section of the transport network when their percentage in the total number of cars is low leads to a slight deterioration of traffic conditions, a further increase in the percentage of BEVs (up to 20\%) improves driving conditions for other road users. However, for high percentages of BEVs, the interpretation of results for other cars becomes impossible (the anecdotal criterion). The studies conducted by Zhang et al. [96] show that access to bus lanes may have a negative impact on individual consumers, which could be caused by their concerns regarding dense traffic on public lanes for buses resulting from a growing number of BEVs on the road (which is unfavourable for EV users, as the privilege of using bus lanes then ceases to be effective). Our study confirms that a growth in the number of BEVs translates into worse driving conditions for their users. An additional issue from privileging EV drivers may be the fact that they are not familiar with the rules of traffic management that are specifically dedicated to mass 
transit (e.g., different-looking traffic signals). However, this problem does not affect the analysed case, as city buses use the same traffic lights as private car users

Table 6. Changes in selected traffic parameters in comparison to (base) scenario I for the total number of vehicles and their individual classes.

\begin{tabular}{|c|c|c|c|c|c|c|c|c|c|c|c|c|c|c|c|c|}
\hline & \multicolumn{16}{|c|}{ Changes in Averages Differences between Optimal (Ideal, Theoretical) Driving Time in Comparison to Scenario I [\%] } \\
\hline & II & III & IV & V & VI & VII & VIII & IX & $\mathbf{X}$ & XI & XII & XIII & XIV & $\mathbf{X V}$ & XVI & XVII \\
\hline Total & $0.0 \%$ & $0.0 \%$ & $0.0 \%$ & $0.1 \%$ & $-0.3 \%$ & $-0.4 \%$ & $0.7 \%$ & $0.9 \%$ & $0.7 \%$ & $-1.6 \%$ & $-2.6 \%$ & $0.9 \%$ & $-2.9 \%$ & $-2.2 \%$ & $-0.8 \%$ & $-1.2 \%$ \\
\hline Cars & $0.0 \%$ & $0.0 \%$ & $0.0 \%$ & $0.1 \%$ & $-0.4 \%$ & $-0.4 \%$ & $0.7 \%$ & $0.9 \%$ & $0.7 \%$ & $-1.7 \%$ & $-2.8 \%$ & $0.9 \%$ & $-3.0 \%$ & $-2.2 \%$ & $-0.9 \%$ & $-1.3 \%$ \\
\hline BEVs & & $-43.5 \%$ & $-39.0 \%$ & $-20.1 \%$ & $13.4 \%$ & $-0.8 \%$ & $22.1 \%$ & $9.3 \%$ & $12.2 \%$ & $-1.2 \%$ & $-1.5 \%$ & $-3.0 \%$ & $-9.3 \%$ & $-10.5 \%$ & $-6.9 \%$ & $-1.3 \%$ \\
\hline $\begin{array}{l}\text { Other } \\
\text { cars }\end{array}$ & $0.0 \%$ & $0.3 \%$ & $0.4 \%$ & $0.4 \%$ & $-0.7 \%$ & $-0.4 \%$ & $0.3 \%$ & $0.9 \%$ & $0.2 \%$ & $-1.8 \%$ & $-3.0 \%$ & $2.3 \%$ & $1.3 \%$ & $6.8 \%$ & $20.3 \%$ & \\
\hline Buses & $0.0 \%$ & $0.0 \%$ & $0.0 \%$ & $-0.7 \%$ & $0.9 \%$ & $0.9 \%$ & $0.7 \%$ & $0.7 \%$ & $0.6 \%$ & $0.6 \%$ & $-2.0 \%$ & $0.6 \%$ & $-1.9 \%$ & $-1.5 \%$ & $0.9 \%$ & $0.9 \%$ \\
\hline & \multicolumn{16}{|c|}{ Average durations of the state "in queue" of the vehicle in comparison to scenario I [\%] } \\
\hline Total & $0.0 \%$ & $0.0 \%$ & $0.0 \%$ & $0.1 \%$ & $-0.3 \%$ & $-0.3 \%$ & $0.8 \%$ & $1.1 \%$ & $0.8 \%$ & $-1.4 \%$ & $-2.7 \%$ & $0.9 \%$ & $-3.3 \%$ & $-2.7 \%$ & $-1.2 \%$ & $-1.7 \%$ \\
\hline Cars & $0.0 \%$ & $0.0 \%$ & $0.0 \%$ & $0.2 \%$ & $-0.3 \%$ & $-0.4 \%$ & $0.9 \%$ & $1.2 \%$ & $0.8 \%$ & $-1.4 \%$ & $-2.9 \%$ & $0.9 \%$ & $-3.3 \%$ & $-2.7 \%$ & $-1.3 \%$ & $-1.8 \%$ \\
\hline BEVs & - & $-43.3 \%$ & $-36.4 \%$ & $-15.3 \%$ & $19.2 \%$ & $2.5 \%$ & $27.3 \%$ & $12.5 \%$ & $15.0 \%$ & $-0.1 \%$ & $-3.2 \%$ & $-4.8 \%$ & $-11.5 \%$ & $-12.8 \%$ & $-8.3 \%$ & $-1.8 \%$ \\
\hline $\begin{array}{l}\text { Other } \\
\text { cars }\end{array}$ & $0.0 \%$ & $0.3 \%$ & $0.4 \%$ & $0.4 \%$ & $-0.8 \%$ & $-0.4 \%$ & $0.2 \%$ & $1.0 \%$ & $0.1 \%$ & $-1.6 \%$ & $-2.8 \%$ & $2.9 \%$ & $2.3 \%$ & $8.4 \%$ & $23.6 \%$ & - \\
\hline Buses & $0.0 \%$ & $0.0 \%$ & $0.0 \%$ & $-1.3 \%$ & $0.8 \%$ & $0.8 \%$ & $0.5 \%$ & $0.6 \%$ & $0.8 \%$ & $0.4 \%$ & $-2.8 \%$ & $0.2 \%$ & $-2.3 \%$ & $-2.7 \%$ & $1.0 \%$ & $0.3 \%$ \\
\hline & \multicolumn{16}{|c|}{ Average frequencies of changes to the state "in queue" in comparison to scenario I [\%] } \\
\hline Total & $0.0 \%$ & $0.0 \%$ & $0.0 \%$ & $-3.0 \%$ & $-3.3 \%$ & $-3.5 \%$ & $-2.2 \%$ & $-2.6 \%$ & $-1.0 \%$ & $-3.7 \%$ & $-4.9 \%$ & $-0.1 \%$ & $-2.3 \%$ & $-1.6 \%$ & $0.9 \%$ & $0.1 \%$ \\
\hline Cars & $0.0 \%$ & $0.0 \%$ & $0.0 \%$ & $-3.1 \%$ & $-3.5 \%$ & $-3.6 \%$ & $-2.3 \%$ & $-2.6 \%$ & $-1.2 \%$ & $-4.2 \%$ & $-5.2 \%$ & $-0.4 \%$ & $-2.4 \%$ & $-1.6 \%$ & $1.1 \%$ & $0.0 \%$ \\
\hline BEVs & - & $-36.0 \%$ & $-48.8 \%$ & $-36.0 \%$ & $-9.3 \%$ & $-20.0 \%$ & $9.8 \%$ & $2.8 \%$ & $14.3 \%$ & $-7.4 \%$ & $0.4 \%$ & $1.3 \%$ & $-5.3 \%$ & $-2.4 \%$ & $-1.0 \%$ & $0.0 \%$ \\
\hline $\begin{array}{l}\text { Other } \\
\text { cars }\end{array}$ & $0.0 \%$ & $0.2 \%$ & $0.5 \%$ & $-2.5 \%$ & $-3.3 \%$ & $-3.1 \%$ & $-2.1 \%$ & $-2.2 \%$ & $-1.6 \%$ & $-3.7 \%$ & $-6.4 \%$ & $-1.0 \%$ & $-0.5 \%$ & $-0.7 \%$ & $8.5 \%$ & - \\
\hline Buses & $0.0 \%$ & $0.0 \%$ & $0.0 \%$ & $-1.8 \%$ & $-1.8 \%$ & $-1.8 \%$ & $-1.8 \%$ & $-3.6 \%$ & $1.8 \%$ & $1.8 \%$ & $-3.6 \%$ & $3.6 \%$ & $-1.8 \%$ & $-1.8 \%$ & $-1.8 \%$ & $1.8 \%$ \\
\hline
\end{tabular}

Table 6 presents the analytical scale for which it is impossible to perform an unambiguous statistical assessment of the impact that privileging BEVs has on bus traffic. Therefore, attempts to determine the phenomenon should be made through analysis (of high temporal resolution) that focuses on individual bus journeys, which would enable a more precise and clear-cut determination of the causes behind changes to the base scenario. A graphic illustration of said analyses is presented in Figure 8. For almost all bus journeys, a rise in the percentage of BEVs resulted in a delay for the state "in queue" at the beginning of their journey through the analysed section of the network (BEVs that intend to go straight across the intersection block other vehicles wishing to turn right, thereby expanding the queue on the bus lane). During the subsequent stages through the researched area, the queueing times were practically unchanged (both in terms of the temporal distribution of queues and the time spent in a queue). In Table 6, the changes in time that are noticeable were caused by one case (shown in Figure 9), which is the effect of a disparity between differences in timetabled bus frequency on the bus lane and the cycle length of the traffic signal. These small changes are thought-provoking - after all, one would expect that limited space on bus lanes due to BEV privileging would worsen traffic conditions for buses. However, this effect was not observed in our study, which can be explained by the fact that bus lanes are usually separated from other lanes by a long stretch of solid line (indicating no crossing it), which makes them less attractive for BEV drivers intending to turn left ahead or even join the bus lane when the BEV is driving along a regular lane. Furthermore, the vast majority of bus lanes can only be joined from the intersection that precedes them. These issues are stressed by Sendek-Matysiak and Łosiewicz [97], who argue that bus lanes are difficult for $\mathrm{BEVs}$ to enter and exit in many locations due to traffic restrictions or congestion on the remaining lanes. Moreover, the same authors also state that the problems with bus lanes and BEVs may be due to the somewhat confusing road markings that often discourage road users. 


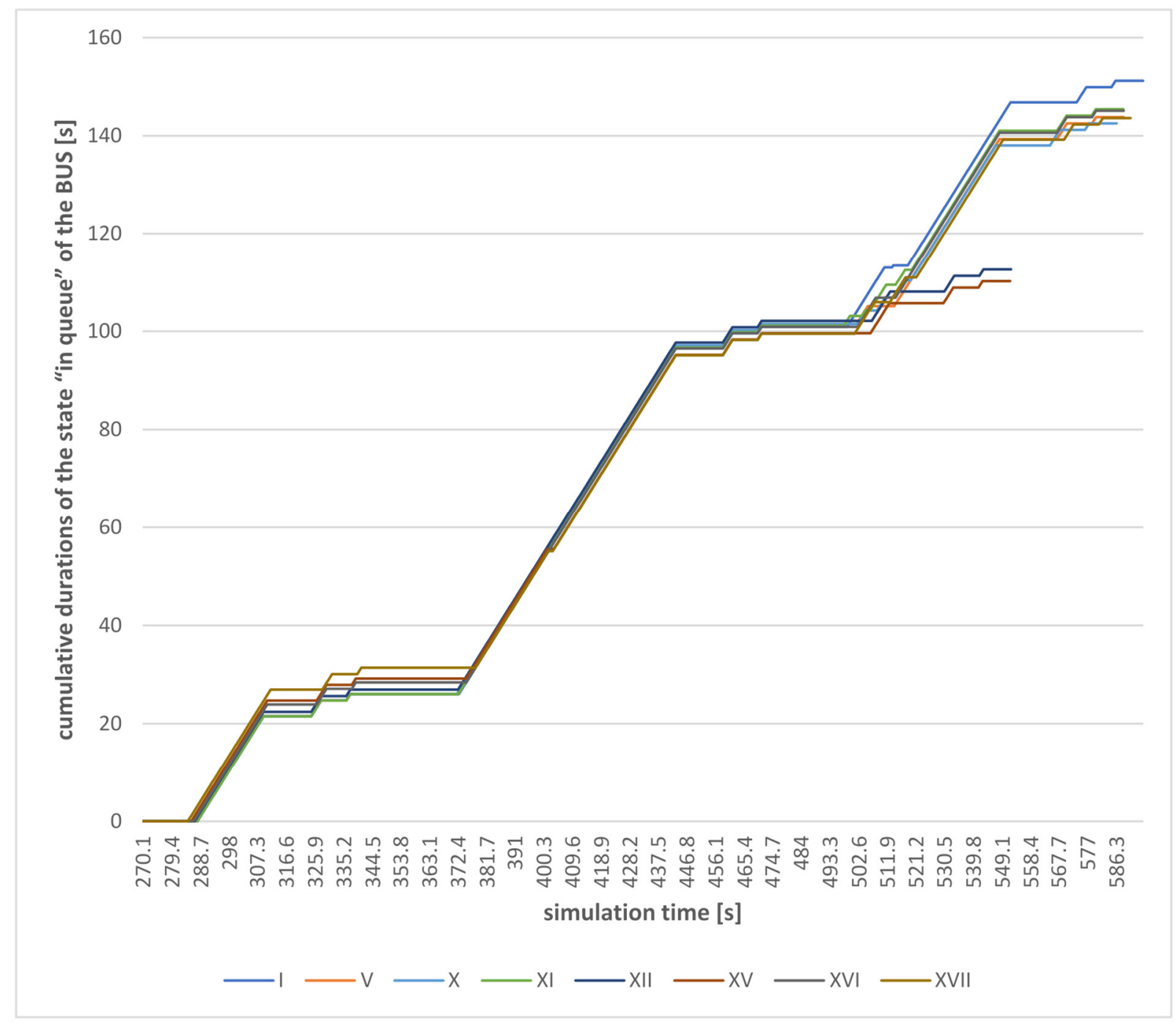

Figure 9. Durations of the state "in queue" for Bus 81 heading towards the Sikawa district in selected scenarios.

\section{Conclusions}

The purpose of this article was to determine the impact on the equilibrium of the local transport system from privileging EVs by permitting them to use bus lanes. Creating incentives to promote the purchase and use of a BEV is crucial in the context of creating transport systems suited to the principles of sustained urban mobility. However, incentives must be tailored to the given city and its residents. For instance, privileging BEVs with access to bus lanes does result in a rise in their percentage, but only to a limited extent, and the situation changes once a certain threshold of BEVs in the total number of cars is exceeded; this is because an increase in BEVs may make the privilege of using bus lanes less attractive for their users, as also shown by the results of our simulations. Such analyses are important not only from the methodological point of view, but also from the applicational perspective-by adopting the appropriate incentive, the city involved may encourage private users to buy a BEV.

Simulations that we have carried out can contribute to reliable uncertainty management, because uncertainty quantification could permit users to get more useful information for privileging EVs. Construction and analysis of simulation-based traffic models allows us to determine how likely certain outcomes are if certain aspects of the city transport system are not known in detail. One example of this could be forecasting delays in the performance of transport tasks by public transport vehicles with full knowledge of their timetables when bus lanes can be used by electric vehicles. The appearance of a private 
transport vehicle before the bus rather than immediately behind it may result in a situation where the public transport vehicle has to wait for the next phase of the traffic lights in order to be able to move, which may cause delays of up to several minutes at subsequent stops. Through a series of simulations we can obtain a group of different results that are only statistically predictable. This makes it possible to estimate the scale of possible time disruptions and, if necessary, to introduce the necessary organisational solutions (e.g., removal of an unnecessary bus lane).

Our analysis and similar studies provide diagnostic material that facilitates better policymaking when privileging EVs, and improves flexibility in terms of their changeability in time and space. They also show the threshold percentage of EVs for which privileging may return counterproductive results not only for EVs themselves, but also for other road users-including the efficiency of public transport, the most fundamental keystone of any policy of sustainable urban mobility.

The analyses carried out have produced interesting results with regard to both the research problem and several other aspects concerning the functioning of the local transport system. This justifies the need for further experiments and analyses, taking into account other research polygons (e.g., different traffic generators, different traffic organisation) and other equilibrium levels of the transport system (e.g., a different traffic peak period). This would allow for a broader and more accurate characterisation of the analysed phenomena, taking into account a group of case studies corresponding to the diversity of the urban transport system environment. Treating this study as initiating a series of further analyses, it should be pointed out that the obtained preliminary results strongly justify further in-depth research.

However, further studies could include the aspect of charging stations and their distribution, because the decision to purchase a BEV (and, thus, a rise in the share of electric cars among all vehicles on the urban network) is strongly correlated with the accessibility of charging points. This knowledge could also be utilised to assess the costs and benefits of building a network of charging stations.

Electric vehicles are the future for the world. Increasing their quantity will have a positive impact on the environment — which is confirmed by numerous studies [98,99] — but will also allow us to meet the requirements of sustainable development. However, one should not forget about the impact of this type of vehicle on the energy sector-including the costs of electricity, or the methods of its production; this is confirmed by the results of research conducted by Hassoun and Al-Sahili [100]. In addition, research related to the charging infrastructure-including the impact of the EV charging station loads on the electricity distribution network—cannot be neglected, as noted by Deb et al. [17]. In our article, we, in turn, attempted to evaluate the incentives and privileges introduced for users of this type of vehicle for urban transport systems, because this is an extremely important issue, and still very rarely discussed. The results of these studies are important for introducing recommendations for transport policies and documents related to sustainable development, not only at the local but also at the global level. This is also confirmed by the growing interest in this subject on the part of scientists, which translates into a greater number of publications in the field of EVs.

Author Contributions: Conceptualization, S.W. and M.K.; methodology, M.K. and M.M.; software, M.K.; validation, M.B.-S., M.K., P.K. and S.W.; formal analysis, M.B.-S., M.K., P.K. and S.W.; investigation, M.B.-S., M.K., P.K. and S.W.; resources, M.K.; data curation, M.K. and S.W.; writing-original draft preparation, M.B.-S., M.K., P.K. and S.W.; writing-review and editing, M.B.-S., M.K., P.K. and S.W.; visualization, M.K. and S.W.; supervision, M.B.-S., M.K., P.K.; M.M. and S.W.; project administration, M.K. and S.W.; funding acquisition, M.K. and S.W. All authors have read and agreed to the published version of the manuscript.

Funding: This research was produced under the research projects no. 2019/33/N/HS4/01733 and 2019/35/D/HS4/00697, financed by funding from the National Science Centre in Poland.

Institutional Review Board Statement: Not applicable. 
Informed Consent Statement: Not applicable.

Conflicts of Interest: The authors declare no conflict of interest.

\section{References}

1. Komornicki, T. Przemiany Mobilności Codziennej Polaków na tle Rozwoju Motoryzacji [Transformations in the Daily Mobility of Poles against the Background of Development of Car Ownership]; IGiPZ PAN: Warsaw, Poland, 2011; Volume 227.

2. Fujii, S.; Gärling, T.; Kitamura, R. Changes in drivers' perceptions and use of public transport during a freeway closure: Effects of temporary structural change on cooperation in a real-life social dilemma. Environ. Behav. 2001, 33, 796-808. [CrossRef]

3. Electromobility Development Plan in Poland.'Energy for the Future; Ministry of Energy: Warsaw, Poland, 2017.

4. Taczanowski, J.; Kołoś, A.; Gwosdz, K.; Domański, B.; Guzik, R. The development of low-emission public urban transport in Poland. Bull. Geogr. 2018, 41, 79-92. [CrossRef]

5. Manzetti, S.; Mariasiu, F. Electric vehicle battery technologies: From present state to future systems. Renew. Sustain. Energy Rev. 2015, 51, 1004-1012. [CrossRef]

6. Young, K.; Wang, C.; Strunz, K. Electric vehicle battery technologies. In Electric Vehicle Integration into Modern Power Networks; Springer: Berlin/Heidelberg, Germany, 2013; pp. 15-56.

7. Fotouhi, A.; Auger, D.J.; Propp, K.; Longo, S.; Wild, M. A review on electric vehicle battery modelling: From Lithium-ion toward Lithium-Sulphur. Renew. Sustain. Energy Rev. 2016, 56, 1008-1021. [CrossRef]

8. Liu, K.; Hu, X.; Zhou, H.; Tong, L.; Widanalage, D.; Macro, J. Feature Analyses and Modelling of Lithium-ion Batteries Manufacturing based on Random Forest Classification. IEEE/ASME Trans. Mechatron. 2021, 1-11. [CrossRef]

9. Liu, K.; Li, Y.; Hu, X.; Lucu, M.; Widanage, W.D. Gaussian Process Regression with Automatic Relevance Determination Kernel for Calendar Aging Prediction of Lithium-Ion Batteries. IEEE Trans. Ind. Inform. 2020, 16, 3767-3777. [CrossRef]

10. Liu, K.; Hu, X.; Wei, Z.; Li, Y.; Jiang, Y. Modified Gaussian process regression models for cyclic capacity prediction of lithium-ion batteries. IEEE Trans. Transp. Electrif. 2019, 5, 1225-1236. [CrossRef]

11. Liu, K.; Shang, Y.; Ouyang, Q.; Widanage, W.D. A Data-Driven Approach with Uncertainty Quantification for Predicting Future Capacities and Remaining Useful Life of Lithium-ion Battery. IEEE Trans. Ind. Electron. 2021, 68, 3170-3180. [CrossRef]

12. Liu, K.; Wei, Z.; Yang, Z.; Li, K. Mass load prediction for lithium-ion battery electrode clean production: A machine learning approach. J. Clean. Prod. 2021, 289, 125159. [CrossRef]

13. Abdelbaky, M.; Peeters, J.R.; Dewulf, W. On the influence of second use, future battery technologies, and battery lifetime on the maximum recycled content of future electric vehicle batteries in Europe. Waste Manag. 2021, 125, 1-9. [CrossRef] [PubMed]

14. Kowalska-Pyzalska, A.; Kott, J.; Kott, M. Why Polish market of alternative fuel vehicles (AFVs) is the smallest in Europe? SWOT analysis of opportunities and threats. Renew. Sustain. Energy Rev. 2020, 133, 110076. [CrossRef]

15. Un-Noor, F.; Padmanaban, S.; Mihet-Popa, L.; Mollah, M.N.; Hossain, E. A comprehensive study of key electric vehicle (EV) components, technologies, challenges, impacts, and future direction of development. Energies 2017, 10, 1217. [CrossRef]

16. Ali, M.U.; Zafar, A.; Nengroo, S.H.; Hussain, S.; Alvi, M.J.; Kim, H.J. Towards a Smarter Battery Management System for Electric Vehicle Applications: A Critical Review of Lithium-Ion Battery State of Charge Estimation. Energies 2019, 12, 446. [CrossRef]

17. Deb, S.; Tammi, K.; Kalita, K.; Mahanta, P. Impact of electric vehicle charging station load on distribution network. Energies 2018, 11, 178. [CrossRef]

18. Collin, R.; Miao, Y.; Yokochi, A.; Enjeti, P.; Von Jouanne, A. Advanced electric vehicle fast-charging technologies. Energies 2019, 12, 1839. [CrossRef]

19. Varga, B.O.; Sagoian, A.; Mariasiu, F. Prediction of electric vehicle range: A comprehensive review of current issues and challenges. Energies 2019, 12, 946. [CrossRef]

20. Thiel, C.; Tsakalidis, A.; Jäger-Waldau, A. Will electric vehicles be killed (again) or are they the next mobility killer app? Energies 2020, 13, 1828. [CrossRef]

21. Grijalva, E.R.; López Martínez, J.M. Analysis of the reduction of $\mathrm{CO}_{2}$ emissions in urban environments by replacing conventional city buses by electric bus fleets: Spain case study. Energies 2019, 12, 525. [CrossRef]

22. Sierpiński, G.; Staniek, M.; Kłos, M.J. Decision making support for local authorities choosing the method for siting of in-city ev charging stations. Energies 2020, 13, 4682. [CrossRef]

23. Canizes, B.; Soares, J.; Costa, A.; Pinto, T.; Lezama, F.; Novais, P.; Vale, Z. Electric vehicles' user charging behaviour simulator for a smart city. Energies 2019, 12, 1470. [CrossRef]

24. Ruggieri, R.; Ruggeri, M.; Vinci, G.; Poponi, S. Electric Mobility in a Smart City: European Overview. Energies 2021, $14,315$. [CrossRef]

25. Borowska-Stefańska, M.; Wiśniewski, S.; Kowalski, M. Funkcjonowanie roweru publicznego w dużym mieście: Przykład Łodzi [Functioning of a Public Bike in a Big City: The Example of Łódź]; Wydawnictwo Uniwersytetu Łódzkiego: Łódź, Poland, 2020.

26. Waas, T.; Hugé, J.; Verbruggen, A.; Wright, T. Sustainable development: A bird's eye view. Sustainability 2011, 3, 1637-1661. [CrossRef]

27. Raszkowski, A.; Bartniczak, B. On the road to sustainability: Implementation of the 2030 Agenda sustainable development goals (SDG) in Poland. Sustainability 2019, 11, 366. [CrossRef]

28. Urbanek, A. Pomiar zrównoważonej mobilności miejskiej: Przegląd badań [Measuring sustainable urban mobility: Review of research]. Stud. i Pr. Kol. Zarządzania i Finans. Zesz. Nauk. 2019, 171, 61-80. 
29. Sosik, K. Współczesne Miejskie Systemy Transportowe W Kontekście Zrównoważonego Rozwoju W Polsce [Modern Urban Transport Systems In Context Of Sustainable Development In Poland]. Zesz. Nauk. Politech. Częstochowskiej Zarzadzanie 2020, 39, 49-63. [CrossRef]

30. Borowska-Stefańska, M.; Wiśniewski, S. Mobilność codzienna osób Straszych w Łodzi [Daily Mobility of the Elderly in Łódż]; Wydawnictwo Uniwersytetu Łódzkiego: Łódź, Poland, 2019.

31. Rześny-Cieplińska, J.; Szmelter-Jarosz, A.; Moslem, S. Priority-based stakeholders analysis in the view of sustainable city logistics: Evidence for Tricity, Poland. Sustain. Cities Soc. 2021, 67. [CrossRef]

32. Nijkamp, J.E.; Mobach, M.P. Developing healthy cities with urban facility management. Facilities 2020, 38, 819-833. [CrossRef]

33. Peterson, M.; Epler, R. Sustainability Developments in Cities of the World. In Continuing to Broaden the Marketing Concept (Review of Marketing Research); Iacobucci, D., Ed.; Emerald Publishing Limited: Bingley, UK, 2020; Volume 17, pp. 243-260. [CrossRef]

34. Załoga, E.; Kłos, Z. Transport miejski w polityce transportowej Unii Europejskiej [Urban transport in european transport policy]. Zesz. Nauk. Probl. Transp. Logistyki/Uniwersytet Szczeciński 2011, 644, 145-152.

35. Brzustewicz, P. Zrównoważone rozwiązania w transporcie miejskim-kierunki rozwoju [Sustainable solutions for urban transportdirections of development]. Acta Univ. Nicolai Copernici Zarzadzanie 2013, 40, 85-96. [CrossRef]

36. Wołek, M.; Wolański, M.; Bartłomiejczyk, M.; Wyszomirski, O.; Grzelec, K.; Hebel, K. Ensuring sustainable development of urban public transport: A case study of the trolleybus system in Gdynia and Sopot (Poland). J. Clean. Prod. 2021, 279. [CrossRef]

37. Russo, F.; Comi, A. City Characteristics and Urban Goods Movements: A Way to Environmental Transportation System in a Sustainable City. Procedia Soc. Behav. Sci. 2012, 39, 61-73. [CrossRef]

38. Cherrett, T.; Allen, J.; McLeod, F.; Maynard, S.; Hickford, A.; Browne, M. Understanding urban freight activity-key issues for freight planning. J. Transp. Geogr. 2012, 24, 22-32. [CrossRef]

39. Taniguchi, E. Concepts of City Logistics for Sustainable and Liveable Cities. Procedia Soc. Behav. Sci. 2014, 151, 310-317. [CrossRef]

40. Kijewska, K.; Iwan, S. Analysis of the Functioning of Urban Deliveries in the City Centre and its Environmental Impact Based on Szczecin Example. Transp. Res. Procedia 2016, 12, 739-749. [CrossRef]

41. Chodkowska-Miszczuk, J.; Lewandowska, A. Kreowanie zrównoważonego transportu miejskiego na przykładzie Kopenhagiwybrane aspekty [Creating a sustainable urban transport on the case study of Copenhagen-selected aspects]. Pr. Kom. Geogr. Komun. PTG 2018, 21, 45-59. [CrossRef]

42. Zawieska, J.; Pieriegud, J. Smart city as a tool for sustainable mobility and transport decarbonisation. Transp. Policy 2018, 63, 39-50. [CrossRef]

43. Adamik, A.; Sikora-Fernandez, D. Smart Organizations as a Source of Competitiveness and Sustainable Development in the Age of Industry 4.0: Integration of Micro and Macro Perspective. Energies 2021, 14, 1572. [CrossRef]

44. Okraszewska, R.; Romanowska, A.; Wołek, M.; Oskarbski, J.; Birr, K.; Jamroz, K. Integration of a multilevel transport system model into sustainable Urban mobility planning. Sustainability 2018, 10, 479. [CrossRef]

45. Johansen, S.K. E-Mobility Maturity Model: Measuring E-Mobility Readiness of Countries. Master's Thesis, Mannheim University, Department of Information Systems II, Mannheim, Germany, 16 January 2018.

46. Higueras-Castillo, E.; Liébana-Cabanillas, F.J.; Muñoz-Leiva, F.; García-Maroto, I. Evaluating consumer attitudes toward electromobility and the moderating effect of perceived consumer effectiveness. J. Retail. Consum. Serv. 2019, 51, 387-398. [CrossRef]

47. Pietrzak, K.; Pietrzak, O. Environmental effects of electromobility in a sustainable urban public transport. Sustainability 2020, 12, 1052. [CrossRef]

48. Hawkins, T.R.; Singh, B.; Majeau-Bettez, G.; Strømman, A.H. Comparative Environmental Life Cycle Assessment of Conventional and Electric Vehicles. J. Ind. Ecol. 2013, 17, 53-64. [CrossRef]

49. Rieckhof, R.; May, N.; Scope, C.; Günther, E. Ökonomisch-ökologischer Nettoeffekt der Elektromobilität im öffentlichen Personennahverkehr. uwf UmweltWirtschaftsForum 2016, 24, 107-119. [CrossRef]

50. Verheijen, E.; Jabben, J. Effect of Electric Cars on Traffic Noise and Safety. 2010. Available online: https:/ / rivm.openrepository. com/bitstream/handle/10029/261949/680300009.pdf?sequence=3 (accessed on 25 April 2021).

51. Elsom, D. Smog Alert: Managing Urban Air Quality; Routledge: New York, NY, USA, 2014.

52. Straka, M.; Chovan, T.; Bindzár, P.; Žatkovič, E.; Hricová, R. Possibilities and Limitations of Electromobiles Utilization. Appl. Mech. Mater. 2014, 708, 159-164. [CrossRef]

53. Shafiei, E.; Davidsdottir, B.; Stefansson, H.; Asgeirsson, E.I.; Fazeli, R.; Gestsson, M.H.; Leaver, J. Simulation-based appraisal of tax-induced electro-mobility promotion in Iceland and prospects for energy-economic development. Energy Policy $2019,133$. [CrossRef]

54. Schickram, S.; Gleyzes, D.; Lienkamp, M. Evaluation of the Electromobility Potential Index and results for 46 major cities. In Proceedings of the 2013 World Electric Vehicle Symposium and Exhibition (EVS27), Barcelona, Spain, 17-20 November 2013; pp. 1-9.

55. Ryghaug, M.; Skjølsvold, T.M. Nurturing a regime shift toward electro-mobility in Norway. In The Governance of Smart Transportation Systems; Springer: Berlin/Heidelberg, Germany, 2019; pp. 147-165.

56. Nanaki, E.A.; Kiartzis, S.; Xydis, G.A. Are only demand-based policy incentives enough to deploy electromobility? Policy Stud. 2020, 1-17. [CrossRef]

57. Bühne, J.A.; Gruschwitz, D.; Hölscher, J.; Klötzke, M.; Kugler, U.; Schimeczek, C. How to promote electromobility for European car drivers? Obstacles to overcome for a broad market penetration. Eur. Transp. Res. Rev. 2015, 7. [CrossRef] 
58. Sendek-Matysiak, E. Analysis of the electromobility performance in Poland and proposed incentives for its development. In Proceedings of the 2018 XI International Science-Technical Conference Automotive Safety, Casta, Slovakia, 18-20 April 2018; pp. 1-7.

59. Tucki, K.; Orynycz, O.; Swic, A.; Mitoraj-Wojtanek, M. The development of electromobility in Poland and EU states as a tool for management of $\mathrm{CO}_{2}$ emissions. Energies 2019, 12, 2942. [CrossRef]

60. Drożdż, W.; Starzyński, P. Economic conditions of the development of electromobility in Poland at the background of selected countries. Eur. J. Serv. Manag. 2018, 28, 133-140. [CrossRef]

61. Kłos, M.; Marchel, P.; Paska, J.; Bielas, R.; Błędzińska, M.; Michalski, L.; Wróblewski, K.; Zagrajek, K. Forecast and impact of electromobility development on the Polish Electric Power System. E3S Web Conf. 2019, 84. [CrossRef]

62. Kupczyk, A.; Maczynśka, J.; Redlarski, G.; Tucki, K.; Baczyk, A.; Rutkowski, D. Selected aspects of biofuels market and the electromobility development in Poland: Current trends and forecasting changes. Appl. Sci. 2019, 9, 254. [CrossRef]

63. Połom, M.; Tarkowski, M.; Puzdrakiewicz, K.; Dopierała, Ł. Is It Possible to Develop Electromobility in Urban Passenger Shipping in Post-Communist Countries? Evidence from Gdańsk, Poland. Energies 2020, 13, 6362. [CrossRef]

64. Kousoulidou, M.; Ntziachristos, L.; Mellios, G.; Samaras, Z. Road-transport emission projections to 2020 in European urban environments. Atmos. Environ. 2008, 42, 7465-7475. [CrossRef]

65. Zhou, Q.; Leng, G.; Peng, J. Recent changes in the occurrences and damages of floods and droughts in the United States. Water 2018, 10, 1109. [CrossRef]

66. The American Recovery and Reinvestment Act, Public Law 111-5-FEB. 17, 2009.

67. Leurent, F.; Windisch, E. Triggering the development of electric mobility: A review of public policies. Eur. Transp. Res. Rev. 2011, 3, 221-235. [CrossRef]

68. Wang, H.; Kimble, C. Low-cost strategy through product architecture: Lessons from China. J. Bus. Strategy 2010, 31, 12-20. [CrossRef]

69. Feckova Skrabulakova, E.; Ivanova, M.; Rosova, A.; Gresova, E.; Sofranko, M.; Ferencz, V. On electromobility development and the calculation of the infrastructural country electromobility coefficient. Processes 2021, 9, 222. [CrossRef]

70. Rehák, R. Electromobility in European Union. Ekon. Cest. Ruchu Podn. 2018, 10, 53-63.

71. Electric Vehicles in Urban Europe, Connecting Cities Bulding Successes, European Union, Urbact. 2012. Available online: https:/ / urbact.eu/sites/default/files/import/Projects/EVUE/documents_media/EVUE_report_280912_FINAL.pdf (accessed on 25 April 2021).

72. W kierunku Zeroemisyjnej Mobilności, Czynniki Determinujące Rozwój Napędów Alternatywnych w Samochodach Osobowych i Dostawczych w Unii Europejskiej, [Towards Zero-Emission Mobility, Factors Determining the Development of Alternative Drives in Passenger Cars and Vans in the European Union]. 2020. Available online: https: / / www.pzpm.org.pl/content/download/11562/72254/file/Perspektywy \%20rozwoju\%20samochodo\%CC\%81w\%20z\% 20nape\%CC\%A8dami\%20alternatywnymi\%20_Raport\%20PL.pdf (accessed on 25 April 2021).

73. Ustawa o Elektromobilności i Paliwach Alternatywnych [Act of 11 January 2018 on Electromobility and Alternative Fuels] 2018. Available online: isap.sejm.gov.pl/isap.nsf/DocDetails.xsp?id=WDU20180000317 (accessed on 25 April 2021).

74. Skowrońska-Szmer, A.; Kowalska-Pyzalska, A. Key Factors of Development of Electromobility AMONG Microentrepreneurs: A Case Study from Poland. Energies 2021, 14, 764. [CrossRef]

75. de Lara, F.F.; Marx, R. Comparative positioning between Brazilian subsidiaries and European matrices on Electromobility and carsharing technologies. Res. Transp. Bus. Manag. 2018, 27, 67-74. [CrossRef]

76. May, N. Local environmental impact assessment as decision support for the introduction of electromobility in urban public transport systems. Transp. Res. Part D Transp. Environ. 2018, 64, 192-203. [CrossRef]

77. Helmers, E.; Marx, P. Electric cars: Technical characteristics and environmental impacts. Environ. Sci. Eur. 2012, 24, 1-15. [CrossRef]

78. Chan, C.C. The State of the Art of Electric, Hybrid, and Fuel Cell Vehicles With their superior fuel economy and performance, hybrid vehicles will likely increase in popularity in coming years; further development of control theory for hybrids is essential for their. Proc. IEEE 2007, 95, 704-718. [CrossRef]

79. Tie, S.F.; Tan, C.W. A review of energy sources and energy management system in electric vehicles. Renew. Sustain. Energy Rev. 2013, 20, 82-102. [CrossRef]

80. Zhang, A.; Kang, J.E.; Kwon, C. Multi-day scenario analysis for battery electric vehicle feasibility assessment and charging infrastructure planning. Transp. Res. Part C Emerg. Technol. 2020, 111, 439-457. [CrossRef]

81. Tal, G.; Nicholas, M.A. Studying the PEV market in California: Comparing the PEV, PHEV and hybrid markets. In Proceedings of the 2013 World Electric Vehicle Symposium and Exhibition (EVS27), Barcelona, Spain, 17-20 November 2013; pp. 1-10.

82. Mallig, N.; Heilig, M.; Weiss, C.; Chlond, B.; Vortisch, P. Modelling the weekly electricity demand caused by electric cars. Future Gener. Comput. Syst. 2016, 64, 140-150. [CrossRef]

83. Eberle, U.; Müller, B.; Von Helmolt, R. Fuel cell electric vehicles and hydrogen infrastructure: Status 2012. Energy Environ. Sci. 2012, 5, 8780-8798. [CrossRef]

84. Túry, G. Electromobility in the Automotive Industry. What Role Does Technology Change Play in the Geographic Pattern of Production? Glob. Econ. Obs. 2019, 7, 112-120. 
85. Liebreich, M. Liebreich: Green New Deal-Trumpism with Climate Characteritics. 2019. Available online: www.liebreich.com/ bnef-green-new-deal-trumpism-climate-characteristics/ (accessed on 25 April 2021).

86. RobecoSAM The Sustainability Yearbook. 2014. Available online: www.p-plus.nl/resources/articlefiles/SustainabilityYearbook2 014.pdf (accessed on 25 April 2021).

87. Żochowska, R.; Karon, G. Model kształtowania mobilności miejskiej w ujęciu systemowo-funkcjonalnym [Model for shaping urban mobility-system-functional approach]. Pr. Nauk. Politech. Warsz. 2018, 120, 471-480.

88. Kowalski, M.; Wiśniewski, S. Centrum handlowe jako czynnik ruchotwórczy w transporcie samochodowym-przykład Portu Łódź [A shopping centre as a traffic-generating factor In car transport as exemplified by Port Łódź, Poland]. Przegląd Geogr. 2017, 89, 617-639. [CrossRef]

89. Borowska-Stefańska, M.; Kowalski, M.; Wiśniewski, S. Wewnętrzna samochodowa dostępność transportowa Łodzi w świetle pomiarów z inteligentnych systemów transportowych [Internal car transport accessibility of Łódź in the light of measurements from intelligent transportation systems]. Pr. Geogr. 2019, 159, 7-27.

90. Suliborski, A.; Walkiewicz, D.; Wójcik, M. Dostępność komunikacyjna Łodzi (plansza L) [Transport accessibility of Łódź (board L)]. In Atlas MiastaŁodzi; Liszewski, S., Ed.; Urząd Miasta Łodzi, Łódzkie Towarzystwo Naukowe: Łódź, Poland, 2009.

91. Kowalski, M.; Wiśniewski, S. Dostępność transportowa łódzkich centrów handlowych [Transport Accessibility to the Shopping Centres in Łódź]. Handel Wewnętrzny 2017, 3, 339-357.

92. Borowska-Stefańska, M.; Kowalski, M.; Wiśniewski, S. Changes in urban transport behaviours and spatial mobility resulting from the introduction of statutory Sunday retail restrictions: A case study of Lodz, Poland. Morav. Geogr. Rep. 2020, 28, 29-47. [CrossRef]

93. Borowska-Stefańska, M.; Kowalski, M.; Wiśniewski, S.; Szustowski, B.; Maczuga, M. The impact of statutory sunday trading restrictions ... on the choices of residents of a large polish city with regard to transport behaviours and mobility. Stud. Reg. Lokal. 2020, 82, 33-59. [CrossRef]

94. Rochmińska, A. Atrakcyjność Łódzkich Centrów Handlowych oraz Zachowania Nabywcze i Przestrzenne ich klientów [The Attractiveness of Łódź Shopping Centers as Well as the Purchasing and Spatial Behavior of Their Customers]; UŁ: Łódź, Poland, 2013; ISBN 9788375258653.

95. Uchwała Rady Miejskiej w Łodzi Nr LI/528/97 z dnia 29 Stycznia 1997 [Resolution of the City Council in Łódź No. LI/528/97 of 29 January 1997]. Available online: http:/ / archiwum.bip.uml.lodz.pl/index.php?str=83\&id=2523 (accessed on 25 April 2021).

96. Zhang, Y.; Qian, Z.S.; Sprei, F.; Li, B. The impact of car specifications, prices and incentives for battery electric vehicles in Norway: Choices of heterogeneous consumers. Transp. Res. Part C Emerg. Technol. 2016, 69, 386-401. [CrossRef]

97. Sendek-Matysiak, E.; Łosiewicz, Z. Analysis of the Development of the Electromobility Market in Poland in the Context of the Implemented Subsidies. Energies 2021, 14, 222. [CrossRef]

98. Vidhi, R.; Shrivastava, P. A review of electric vehicle lifecycle emissions and policy recommendations to increase EV penetration in India. Energies 2018, 11, 483. [CrossRef]

99. Zhang, Q.; Ou, X.; Yan, X.; Zhang, X. Electric vehicle market penetration and impacts on energy consumption and $\mathrm{CO}_{2}$ emission in the future: Beijing case. Energies 2017, 10, 228. [CrossRef]

100. Hassouna, F.M.A.; Al-Sahili, K. Future energy and environmental implications of electric vehicles in palestine. Sustainability 2020, 12, 5515. [CrossRef] 